\title{
Proteome Analysis of Differentially Displayed Proteins As a Tool for the Investigation of Symbiosis
}

\author{
Siria H. A. Natera, Nelson Guerreiro, and Michael A. Djordjevic \\ Plant-Microbe Interaction Group, Research School of Biological Sciences, Australian National University, \\ P.O. Box 475, Canberra City, Australia, 2601 \\ Accepted 12 May 2000.
}

Two-dimensional gel electrophoresis was used to identify differentially displayed proteins expressed during the symbiotic interaction between the bacterium Sinorhizobium meliloti strain 1021 and the legume Melilotus alba (white sweetclover). Our aim was to characterize novel symbiosis proteins and to determine how the two symbiotic partners alter their respective metabolisms as part of the interaction, by identifying gene products that are differentially present between the symbiotic and nonsymbiotic states. Proteome maps from control $M$. alba roots, wild-type nodules, cultured $S$. meliloti, and $S$. meliloti bacteroids were generated and compared. Over 250 proteins were induced or up-regulated in the nodule, compared with the root, and over 350 proteins were downregulated in the bacteroid form of the rhizobia, compared with cultured cells. $\mathbf{N}$-terminal amino acid sequencing and matrix-assisted laser desorption/ionization time-of-flight mass spectrometry peptide mass fingerprint analysis, in conjunction with data base searching, were used to assign putative identity to nearly 100 nodule, bacterial, and bacteroid proteins. These included the previously identified nodule proteins leghemoglobin and $\mathrm{NifH}$ as well as proteins involved in carbon and nitrogen metabolism in $S$. meliloti. Bacteroid cells showed down-regulation of several proteins involved in nitrogen acquisition, including glutamine synthetase, urease, a urea-amide binding protein, and a PII isoform, indicating that the bacteroids were nitrogen proficient. The down-regulation of several enzymes involved in polyhydroxybutyrate synthesis and a cell division protein was also observed. This work shows that proteome analysis will be a useful strategy to link sequence information and functional genomics.

Additional keywords: differential protein display, nodulin.

The symbiotic interaction between members of the genera Rhizobium, Bradyrhizobium, Mesorhizobium, Sinorhizobium, and Azorhizobium and plants of the Leguminoseae (legume) family results in the formation of nitrogen-fixing root nodules. Genes from both the plant and these rhizobia play a role in the establishment and maintenance of this interaction (Bladergroen and Spaink 1998; Schultze and Kondorosi 1998), in which the plant supplies reduced carbon to the bacteroid (the

Corresponding author: Michael A. Djordjevic; Fax: 612 62490754; E-mail: michael@rsbs.anu.edu.au nodule-residing form of the bacteria) in exchange for fixed nitrogen. During this interaction many changes can also occur in the metabolism of the rhizobia as part of the occupation of this new environment as a result of the micro-aerobic environment present in the nodule.

The main changes in Rhizobium metabolism between the cultured cells and the bacteroids are the shift from sugar metabolism to $\mathrm{C}_{4}$-dicarboxylic acid metabolism and the shift from ammonium assimilation to ammonium secretion. The switch to the use of $\mathrm{C}_{4}$-dicarboxylic acids means that bacteroids generally do not contain or express the transporters for sugars such as sucrose. Bacteroids also appear to be nitrogen proficient and, in some cases, some amino acid auxotrophs (including glutamate auxotrophs) are still able to form functional nodules. Ammonium transporters expressed in cultured cells are required for nitrogen scavenging but are repressed in the bacteroid (Day and Copeland 1991; Udvardi and Day 1997).

S. meliloti nodulates Melilotus alba and other legumes including Medicago truncatula and M. sativa. The S. meliloti strain 1021 has been proposed as a model microsymbiont and $M$. truncatula as a model legume (Cook 1999). However, $M$. alba, a small-seeded, autogamous, and diploid legume with a small genome and a short stature, has also been recognized as a potentially useful system. This is because $M$. alba is predicted to have many of the same characteristics and patterns of gene expression as M. sativa (Kneen and LaRue 1988), which is tetraploid, and a series of nodulation mutants that are blocked at various stages of bacterial infection and nitrogen fixation have been identified (Utrup et al. 1993).

Recent studies of the changes in gene expression between the cultured and bacteroid states in S. meliloti, R. etli, B. japonicum, and Rhizobium sp. strain NGR234 were conducted to gain a further understanding of how the microsymbiont alters its metabolism to establish and maintain the symbiotic interaction with the host plant (Gage and Long 1998; Girard et al. 1996; Oke and Long 1999; Perret et al. 1999). Girard et al. (1996) studied global transcription patterns of pSym from $R$. etli and found that, during symbiosis, transcription of almost all the genes on this symbiotic plasmid was induced. However, they also showed that poor carbon and nitrogen sources, flavonoids, and low oxygen concentrations also led to pSym gene expression. Oke and Long (1999) also studied the expression of $S$. meliloti genes during symbiosis with a novel promoter trap procedure to identify genes that were expressed in the nodule prior to the establishment of nitrogen fixation. 
However, changes in mRNA expression levels do not necessarily correlate to changes in protein levels (Humphery-Smith et al. 1997).

The techniques of proteome analysis and differential protein display with two-dimensional gel electrophoresis (2-DE) have the power to monitor global changes that occur in the protein expression of a tissue or an organism, and have some advantages over other approaches commonly used for similar studies (Wilkins et al. 1996; Guerreiro et al. 1997). Indeed, Utrup and Norris (1996) used 2-DE differential display of in vitro translation products to identify nodulin and nodule-stimulated products from $M$. alba nodules formed by mutant strains of $S$. meliloti. However, most of these products were not characterized, with the exception of leghemoglobin, which was identified through the use of antibodies. Another example of the use of proteome analysis of symbiotic proteins came from Dainese-Hatt et al. (1999), who identified 38 proteins that were induced in $B$. japonicum by the transition from aerobic to anaerobic or micro-aerobic ( $2 \%$ oxygen) conditions.

To identify the contribution of the microbial and plant proteins to the nodule proteome pattern, we have used a comparative proteome analysis strategy. The proteome pattern of nodules was compared with that of mock-inoculated roots and isolated bacteroid cells. In addition, to understand the changes that occur in microbial gene expression in bacteroids, the proteomes of bacteroids and cultured bacteria were also compared. Put together, these comparisons enable the synthesis and turnover of hundreds of proteins to be monitored under different conditions and for the individual contributions of the interacting organisms to be teased apart and assessed for alterations in protein expression.

The post-separation techniques of $\mathrm{N}$-terminal sequencing and matrix-assisted laser desorption/ionization time-of-flight mass spectrometry (MALDI-TOF MS) in combination with bioinformatics can be used to determine putative identity of many of the individual proteins present. N-terminal sequencing is somewhat slow and expensive compared with MALDITOF MS, which allows a high throughput of samples with rapid analysis times (Shevchenko et al. 1996). In this study, we have used N-terminal sequencing to identify a number of specific nodule proteins and MALDI-TOF MS analysis for a large-scale study of protein identification based on peptide mass fingerprint (PMF) homology.

The utility of PMF data is enhanced in organisms where the entire genome sequence has been determined. In this paper, we have used protein sequencing and PMF data of separated proteins to determine how useful this approach would be for identifying proteins of interest given that the currently available data bases at the time of searching contain limited entries for S. meliloti and M. alba. In the case of S. meliloti, 196 and 306 data base entries could be found in the recent updates of the Swiss-Prot and TrEMBL data bases, respectively. In addition, many of the TrEMBL entries are for open reading frames or hypothetical genes. The complete genome of $S$. meliloti 1021 is currently being sequenced by an international consortium and incomplete DNA sequence data is already available as part of the BLAST server at NCBI or as a incomplete chromosome BLAST server (see Materials and Methods for Web links). A result of this work has been the publication of highresolution maps of the $S$. meliloti chromosome and pSyma plasmid (Capela et al. 1999; Barloy-Hubler et al. 2000).
The work described here contributes additional information to the proposed S. meliloti proteome map (Guerreiro et al. 1999) via PMF matching to complement the genome sequencing. In this paper, we have examined the proteome of root nodules of $M$. alba infected with $S$. meliloti 1021 . We were able to effectively separate the contribution of the microsymbiont to nodule protein content. We present, for the first time, the proteome of $M$. alba root and nodules and the bacteroid state of the model organism $S$. meliloti, using directly isolated proteins.

\section{RESULTS}

\section{Comparison of proteome patterns.}

Over 1,700 individual, abundant proteins were resolved in silver stained proteome maps of mock-inoculated root and root nodule tissue of $M$. alba (Fig. 1A and B), respectively, as determined by analysis of duplicate gels. Upon first inspection, the patterns appear to be different. However, comparison of the two patterns showed that at least 1,300 spots were resolved in identical patterns. Of the remaining proteins, over 250 were either induced or up-regulated in nodule tissue (yellow and green circled spots in Figure 1B) and 20 root proteins were down-regulated in nodule tissue (red circled spots in Figure 1A).

We expected that many of the up-regulated proteins in nodule tissue were of bacterial origin. This was confirmed by comparing the proteome pattern of bacteroid proteins (Fig. 2B) with that of the nodule (Fig. 1B) and uninoculated root (Fig. 1A). This comparison showed that many proteins in nodules had a clear counterpart in bacteroid cells with respect to spot distribution, position, and coloring when stained with silver. An example of this was GroEL, which was identified in the nodule by N-terminal sequence homology (spot 12, Fig. $1 \mathrm{~B}$, and flanking isoforms) and in the bacteroid by PMF homology (spot x78, Fig. 2B; more analysis below). From this analysis, we concluded that over 180 of the up-regulated nodule proteins were from bacteroids (Fig. 2B) while another 70 appeared to be novel to nodule tissues and are potential new nodulins (Fig. 1B).

A comparison of bacteroid and cultured bacteria (both over 1,700 spots per gel) showed that a minimum of 350 proteins are down-regulated in the bacteroid, compared with cultured bacteria (red circled spots in Fig. 2A), and 130 proteins are up-regulated or induced in bacteroids (yellow and green circled spots, respectively, in Figure 2B).

\section{Identification of nodule proteins by $\mathrm{N}$-terminal sequencing.}

Twenty-four nodule proteins, numbered in Figure 1B, were subjected to N-terminal amino acid sequencing. The homology of the protein sequences obtained to a non-redundant protein data base is shown in Table 1.

Six proteins (spots 2, 12, 14, 16, 21, and 22) were predicted to be bacterial on the basis of gel matching. This was confirmed by $\mathrm{N}$-terminal sequence homology. These included spot 12 , homologous to the molecular chaperone GroEL, spot 2 , homologous to a nucleoside diphosphate kinase, and spot 16, homologous to a transcription elongation factor homologue. Spot 14, homologous to a $16-\mathrm{kDa}$, heat-shock protein from Escherichia coli, was reported to be up-regulated in 
cultured S. meliloti at a late-exponential growth phase (Guerreiro et al. 1999). In addition, spot 21 showed homology to the TCA cycle enzyme, isocitrate dehydrogenase (ICD), which is required for effective nodules (McDermott and Kahn 1992). As expected, this spot was present in the nodule, bacteroid, and cultured bacteria. Spot 22 showed homology to enolase, an enzyme of the glycolytic pathway that is required by $S$. meliloti for growth on succinate (Finan et al. 1988).

Spots 3a, 4, 13, and 18 appeared to be plant-specific. Three of these proteins (spots 3a, 4, and 13) displayed homology to the late nodulin, leghemoglobin. Spot 18 did not display any significant homology to proteins in the data bases searched by both fasta 3 and BLAST searches.

Spots 1, 6, 7, 10, and 19 were present in the nodule and bacteroid, but not in control roots or cultured S. meliloti, and are likely to be bacteroid specific. Spots 6 and 7, and spot 19, showed high homology to the nitrogenase genes nifH and nifK, respectively. Spot 1 appeared to be present in both the nodules and bacteroids, but not in roots or cultured $S$. meliloti cells. Spot 1 showed no homology to any proteins currently in the data bases when searched with a fasta 3 search but showed homology to unspecified $S$. meliloti fix genes when a nonredundant BLAST search was performed (data not shown). The fix genes are required for nitrogen fixation and are primarily transcribed under low oxygen conditions found in the nodule (Fischer 1994). Spot 3b showed homology to a ferredoxin-like gene in the nif region from Rhizobium sp. strain NGR234. The location of this protein under spot $3 \mathrm{a}$ in the nodule makes it difficult to assess if this protein is also present in cultured bacteria and bacteroid but, given its identity, this is unlikely. Spots 8 and 10, which are also putatively classed as bacteroid-specific proteins, did not display any clear homology to proteins currently available in the data bases.

Of the predicted plant proteins sequenced, i.e., those present in both root and nodule gels (uncircled, numbered spots, Fig. 1B), homologies were found to (spot 5) calreticulin, an endoplasmic reticulum located calcium-binding protein (Coughlan et al. 1997), and the structural protein $\alpha$-tubulin (spot 15). Spot 9 showed homology to a Bet v 1 protein from a family of plant pathogenesis-related proteins. Spot 17 showed $100 \% \mathrm{~N}$ terminal homology to ascorbate peroxidase 2, an enzyme that uses ascorbate as an electron donor to prevent oxidative damage, especially in nitrogen-fixing legume nodules (Ross et al. 1999). Spot 24 showed homology to a protein disulfide isomerase precursor from $M$. sativa that is involved in the correct folding of proteins. Spots 11 and 23, which are putatively classed as constitutive plant proteins, did not display any clear homology to proteins currently available in the data bases.

\section{PMF analysis of $S$. meliloti proteins.}

A total of 500 proteins from either the bacteroid (nearly 100 proteins) or cultured $S$. meliloti cells (over 400 proteins) were examined by MALDI-TOF MS analysis to generate PMFs. Putative identities based on PMF homology are given in Tables 2, 3, 4, and 5. PMF matches to bacteroid proteins are shown in Tables 2 and 3 while matches to proteins from cultured $S$. meliloti cells are shown in Tables 4 and 5 .

The 13 bacteroid proteins identified were further classified based on whether the levels present were the same as or different from that of the corresponding protein at the same gel location in gels from cultured bacteria. Five bacteroid proteins appeared to be present at the same levels as in the cultured $S$. meliloti gels and were classed as constitutive (Table 2). These included malonyl-CoA decarboxylase, the molecular chaperone GroEL A, 30S ribosomal protein, NAD-dependent malic enzyme (ME), and betaine aldehyde dehydrogenase. MalonylCoA decarboxylase is involved in the malonate-metabolizing pathway that converts malonate to acetyl-CoA in the malonate-rich nodule and may play an important role in symbiosis (An and Kim 1998). Betaine aldehyde dehydrogenase catalyzes the conversion of betaine aldehyde to betaine, which may be used as either a carbon or nitrogen source or as an osmoprotectant in S. meliloti (Pocard et al. 1997). The other eight proteins identified from the bacteroid were up-regulated or induced, compared with their levels in cultured bacteria (Table 3). These included proteins with homology to NifD, DnaK, malate dehydrogenase $(\mathrm{MDH})$, alcohol dehydrogenase $(\mathrm{ADH})$, and four distinct spots with homology to the NifH protein.

Twenty-six proteins from cultured S. meliloti 1021 were tentatively identified on the basis of PMF homology and were classified as either constitutive (Table 4) or down-regulated, compared with levels in the bacteroid (Table 5). All but three of the proteins listed in Table 4 displayed homology to proteins from $S$. meliloti or closely related Rhizobium spp. and included three proteins with homology to $30 \mathrm{~S}$ ribosomal protein S1 and two to GroEL C. Other proteins had homology to $S$. meliloti GroES C and a transcription factor homologue from $R$. leguminosarum, as well as proteins with homology to the PII protein, acetoacetyl-CoA reductase, and ADH. The other three proteins showed homology to A. tumefaciens proteins. Two of these had homology to elongation factor $G$ and the other to elongation factor TU. Table 5 shows 14 proteins that were down-regulated in the bacteroid. These proteins showed homology to proteins involved in the regulation of carbon and nitrogen metabolism, a cell division protein, a protein involved in stationary phase survival, and a putative periplasmic iron-binding protein. Again, all proteins in this class showed homology to proteins from $S$. meliloti or closely related Rhizobium spp.

PMF of equivalent spots from cultured bacteria gels and bacteroid gels was used to confirm that the spots were in fact the same protein. For example, spot $x 89$ from bacteroids is equivalent to spot $\mathrm{z} 57$ from the cultured bacteria and showed PMF homology to $30 \mathrm{~S}$ ribosomal S1 protein. In the case of spots $\mathrm{x} 70$ and a15 from bacteroids, these spots were equivalent to spots 6 and 7 from the nodule, respectively. The PMFs of these matched to the same protein as that identified by $\mathrm{N}$ terminal sequencing, namely, NifH.

Another four proteins, designated rm1, 11, 12, and 14, that were previously sequenced (Guerreiro et al. 1999), were also down-regulated in the bacteroid and are numbered in Figure 2 A. Proteins $\mathrm{rm} 1$ and $\mathrm{rm} 12$ showed homology to a hypothetical amide-urea binding protein and enoyl-CoA hydratase, respectively, while $\mathrm{rm} 11$ and $\mathrm{rm} 14$ did not match to known proteins in a non-redundant protein data base.

\section{S. meliloti data base matching in conjunction with PMF analysis.}

The results of PMF searches against an incomplete $S$. meliloti $1 \mathrm{X}$ genome sequence data base followed by searches 

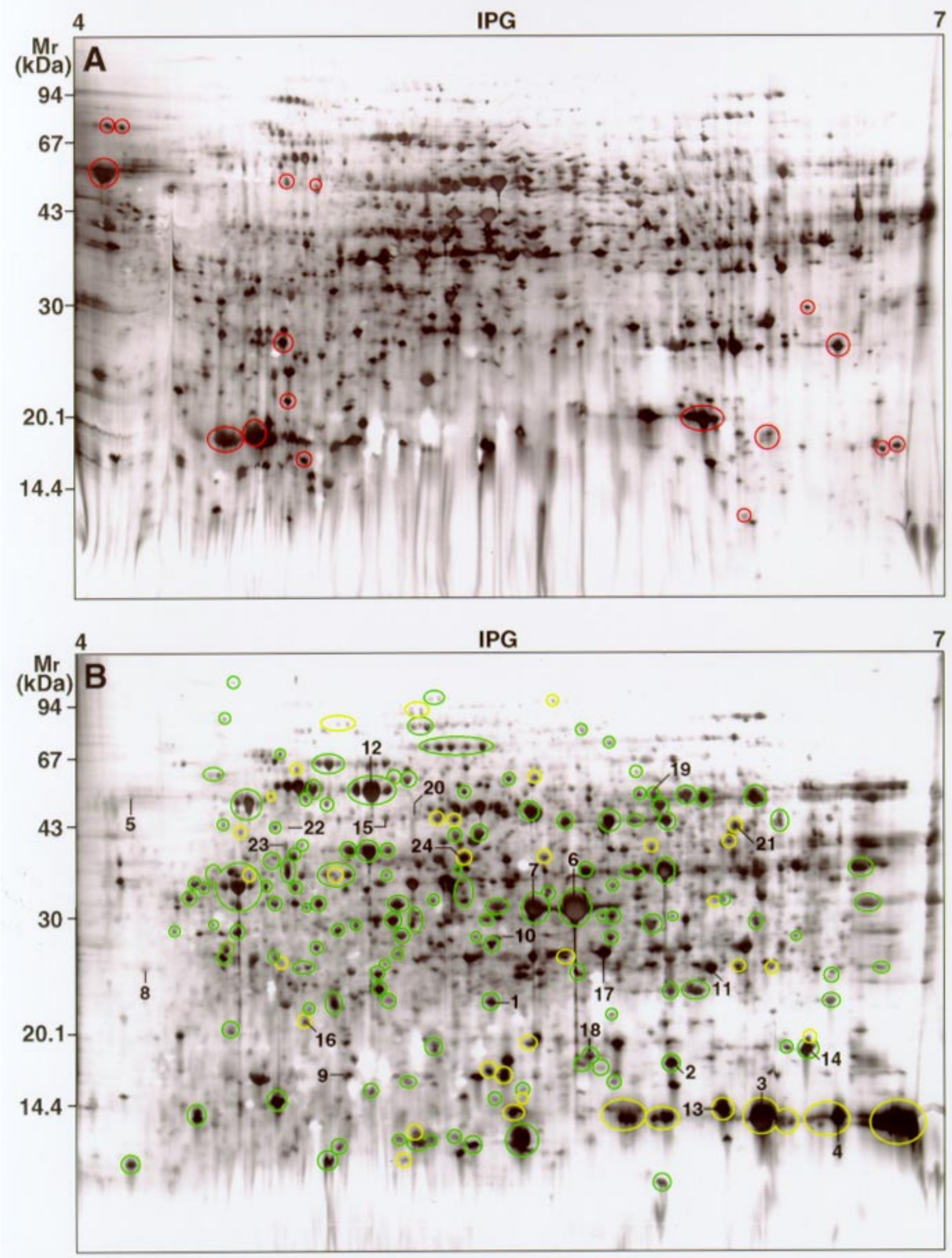

Fig. 1. Two-dimensional gel electrophoresis separation of total protein from wild type Melilotus alba stained with silver nitrate. A, Roots collected 12 days after mock-inoculation. B, Nodules harvested 12 days after inoculation with Sinorhizobium meliloti. Total protein (100 $\mu \mathrm{g})$ was loaded in each case. Comparisons of root and nodule protein maps revealed differences shown where red circles indicate proteins down-regulated in the nodule, green indicates proteins likely to be bacterial in origin by comparison to Figure 2B, and yellow indicates novel nodule proteins. Numbere d proteins correspond to proteins subjected to N-terminal sequencing (see Table 1). Proteins labeled "rm" were previously identified by Guerreiro et al. 1999. 

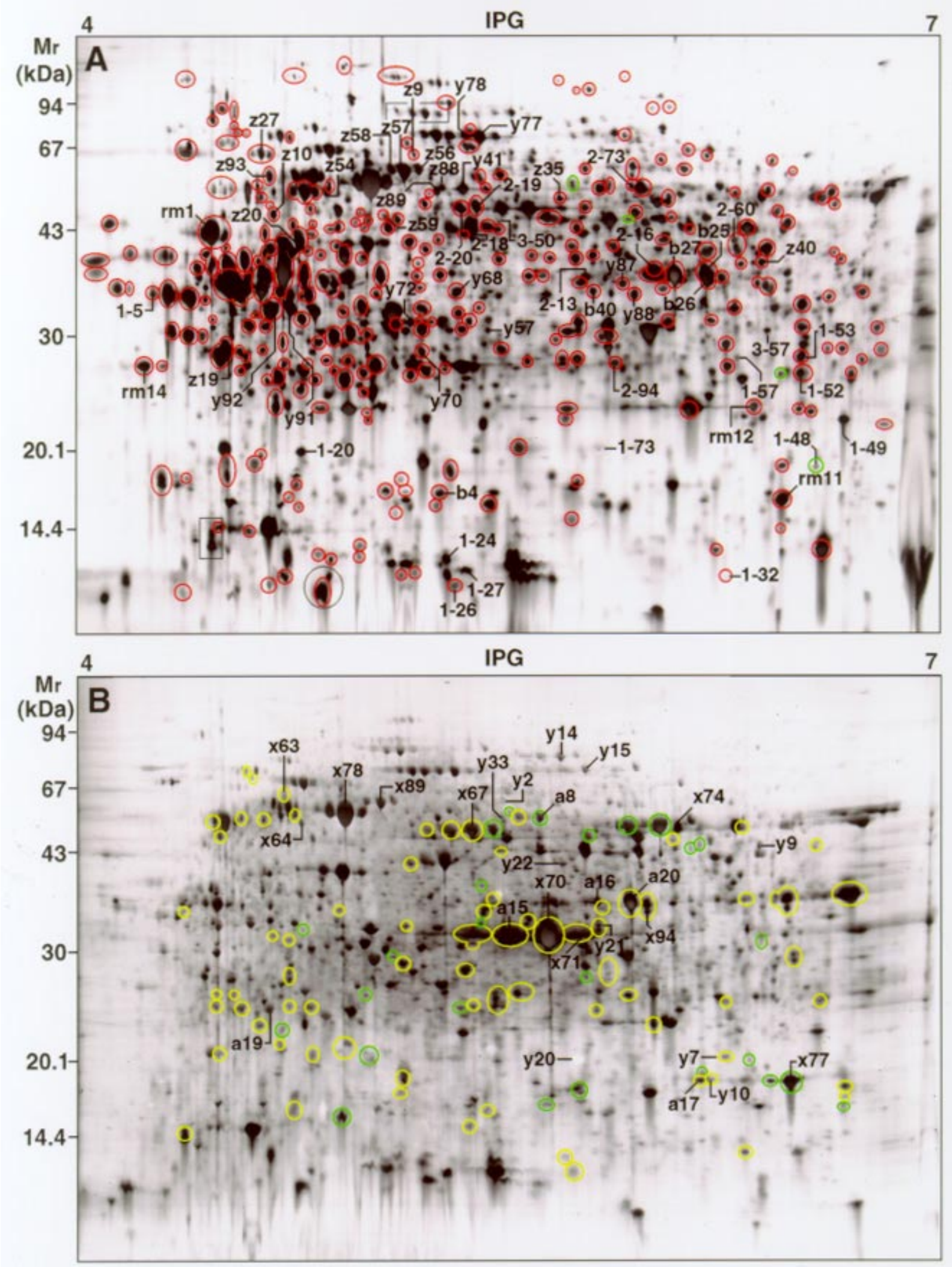

Fig. 2. Two-dimensional gel electrophoresis protein maps of total protein from Sinorhizobium meliloti stained with silver nitrate. A, Proteins from cells grown in culture. B, Bacteroid proteins. Total protein $(100 \mu \mathrm{g})$ was loaded in each case. Red circles indicate proteins down-regulated or switched off in the bacteroid; green, proteins up-regulated in the bacteroid; yellow circles, potentially novel bacteroid proteins. Numbered proteins correspond to examples of proteins subjected to matrix-assisted laser desorption/ionization time-of-flight mass spectrometry (MALDI-TOF MS) analysis (see Tables 2-9). Boxed areas show protein isoform trains; black circle shows isoforms with altered molecular mass. 
against a $S$. meliloti chromosomal BLAST server are listed in Tables 6 to 9 . These proteins were listed in separate tables due to the two-step procedure used to generate PMF matches (see Materials and Methods).

Five up-regulated or novel bacteroid proteins are listed in Table 6. Three proteins in Table 6 showed homology to a small heat-shock protein while another protein showed homology to adenylosuccinate synthetase, which is involved in the de novo biosynthesis of AMP. The other potentially novel bacteroid protein (spot a20) showed a match to a hypothetical protein when a $S$. meliloti data base search was conducted but, when a general protein data base was searched, showed homology to MDH (see Table 3).

Of the eight constitutive proteins listed in Table 7, the homology of two proteins (spots x89 and y15 matching 30S ribosomal protein and ME, respectively) agreed with a more general data base search (see Tables 2 and 7). Six other proteins identified included a hypothetical protein (spot a19) and the beta subunit of glutamyl-tRNA amidotransferase (spot x64), which is involved in ATP-requiring binding of glutamyl-tRNA for translation of nucleic acid sequence into proteins. Spot y9 showed homology to adenylosuccinate lyase, which is involved with the de novo synthesis of purines. In $B$. subtilis, this protein regulates the activity of glutamyl-tRNA synthetase and, as such, the interaction between these two enzymes may play a role in coordinating purine metabolism and protein biosynthesis (Gendron et al. 1992). Spot y2 showed PMF homology to an aminopeptidase $\mathrm{P}$ that is involved in the degradation of small, bioactive peptides. Recently, Barloy-Hubler et al. (2000) showed that a large proportion of the pSyma of $S$. meliloti contains genes involved in the metabolism of small molecules. Spot y14 showed homology to an ATP-dependent protease that may be involved in the degradation of short-lived regulatory and abnormal proteins. Spot y20 showed homology to a single-strand binding protein that is essential for replication of the chromosome and is also involved in DNA recombination and repair.

Table 1. N-terminal sequence of proteins isolated from Melilotus alba nodules ${ }^{\mathrm{a}}$

\begin{tabular}{|c|c|c|c|c|c|c|}
\hline \multicolumn{3}{|c|}{ Nodule protein characteristics } & \multicolumn{4}{|c|}{ Characteristics of matching protein from data base } \\
\hline $\begin{array}{l}\text { Spot } \\
\text { no. }\end{array}$ & $M_{\mathrm{r}} / \mathbf{p I}$ & N-terminal sequence & Protein (\% identity) & Organism & M.w./pI ${ }^{\mathbf{b}}$ & $\begin{array}{l}\text { Swiss-Prot } \\
\text { access. no. }\end{array}$ \\
\hline 1 & $22,000 / 5.47$ & TYKTILLVVGISXEDDLRA & Unknown & & & \\
\hline 2 & $17,100 / 6.06$ & AIERTFSMIK & $\begin{array}{l}\text { Nucleoside diphosphate } \\
\text { kinase [EC 2.7.4.6] }(90 \%)\end{array}$ & Escherichia coli & $15,332 / 5.55$ & P24233 \\
\hline $3 \mathrm{a}^{\mathrm{c}}$ & $13,800 / 6.37$ & QFTEVQEALVQSGAE & Leghemoglobin $(71 \%)$ & $\begin{array}{l}\text { Psophocarpus tetragonolobus } \\
\text { (asparagus bean) }\end{array}$ & $15,551 / 5.90$ & P27199 \\
\hline $3 b^{c}$ & $13,800 / 6.37$ & AFTIVQSQCTNC & $\begin{array}{l}\text { Ferredoxin-like gene in the } \\
\text { NIF-region }(67 \%)\end{array}$ & Rhizobium sp. strain NGR234 & $6,950 / 6.13$ & Q53204 \\
\hline 4 & $13,900 / 6.62$ & GFTEKQETLVNS & Leghemoglobin I (92\%) & Vicia faba (broad bean) & $15,400 / 6.34$ & P02232 \\
\hline 5 & $53,100 / 4.37$ & SVFFEERFE & Calreticulin $(100 \%)$ & Ricinus communis (castor bean) & $47,500 / 4.38$ & P93508 \\
\hline 6 & $33,100 / 5.75$ & AALRQIAFYG & $\begin{array}{c}\text { Nitrogenase reductase [EC } \\
1.18 .6 .1], \text { NifH }(100 \%)\end{array}$ & Sinorhizobium meliloti & $32,023 / 5.44$ & P00460 \\
\hline 7 & $33,100 / 5.62$ & AALRQIAFYG & $\begin{array}{c}\text { Nitrogenase reductase [EC } \\
1.18 .6 .1], \mathrm{NifH}(100 \%)\end{array}$ & S. meliloti & $32,023 / 5.44$ & P00460 \\
\hline 8 & $25,900 / 4.41$ & {$[\mathrm{~S} / \mathrm{M}] \mathrm{RAVLF}(\mathrm{A}) \mathrm{F}(\mathrm{I}) \mathrm{H}$} & No good match & & & \\
\hline 9 & $16,400 / 5.03$ & GVFTFNDEHV & $\begin{array}{l}\text { L1R18B protein, Bet v } 1 \\
\text { family }(78 \%)\end{array}$ & Lupinus luteus (yellow lupine) & $16,600 / 5.35$ & P52779 \\
\hline 10 & $30,300 / 5.50$ & [N/D]IRQEEKGTE & No good match & & & \\
\hline 11 & $26,000 / 6.20$ & NFVIAI[D/V]YPAXRP & No good match & & & \\
\hline 12 & $54,200 / 5.10$ & AAKEV & GroEL & S. meliloti & $57,673 / 5.11$ & P35469 \\
\hline 13 & $14,300 / 6.24$ & GITQKQEALVNGSWE & Leghemoglobin $(80 \%)$ & Vicia faba (broad bean) & $15,875 / 5.90$ & P93849 \\
\hline 14 & $18,000 / 6.52$ & MRHFDFSPLY & $\begin{array}{l}\text { 16-kDa heat-shock protein } \\
(80 \%)\end{array}$ & E. coli & $15,774 / 5.57$ & P29209 \\
\hline 15 & $46,700 / 5.15$ & MRESIRIGFG & $\alpha$-tubulin $(100 \%)$ & Pisum sativum (garden pea) & $49,653 / 4.92$ & P46259 \\
\hline 16 & $20,000 / 4.90$ & VDKVPMTQGG & $\begin{array}{l}\text { Transcription elongation } \\
\text { factor homolog }(80 \%)\end{array}$ & R. leguminosarum & $17,444 / 4.88$ & O68546 \\
\hline 17 & $28,000 / 5.85$ & GKSYPTVSADQKAVE & $\begin{array}{l}\text { Ascorbate peroxidase } 2 \text { [EC } \\
1.11 .1 .11](100 \%)\end{array}$ & Glycine max (soybean) & $27,139 / 5.65$ & Q39843 \\
\hline 18 & $17,600 / 5.80$ & VEDRKVGVAIDFSPRNSN & Unknown & & & \\
\hline 19 & $53,100 / 6.01$ & PQSAEKVLDH & $\begin{array}{l}\text { Nitrogenase component I, } \\
\text { NifK [EC 1.18.6.1] (89\%) }\end{array}$ & Rhizobium sp. strain NGR234 & $57,302 / 5.81$ & P19067 \\
\hline 20 & $48,400 / 5.25$ & $\begin{array}{l}\text { Mixture of proteins - no clear } \\
\text { sequence }\end{array}$ & & & & \\
\hline 21 & $44,600 / 6.28$ & AKIKVANPVV & $\begin{array}{l}\text { Isocitrate dehydrogenase } \\
\text { [NADP] [EC 1.1.1.42] (90\%) }\end{array}$ & Sphingomonas yanoikuyae & $45,483 / 5.17$ & P50215 \\
\hline 22 & $44,300 / 4.84$ & TAIIDIIGREILDSR & Enolase [EC 4.2.1.11] $(67 \%)$ & Nitrosomonas europaea & $46,240 / 4.70$ & O85348 \\
\hline 23 & $41,000 / 4.84$ & XDATLTIESWRNDDLA & No good match & & & \\
\hline 24 & $39,600 / 5.40$ & DDVVVLSEDNFEKEV & $\begin{array}{l}\text { Protein disulfide isomerase } \\
\text { precursor [EC 5.3.4.1] }(87 \%)\end{array}$ & M. sativa (alfalfa) & $40,492 / 5.44$ & P38661 \\
\hline
\end{tabular}

\footnotetext{
${ }^{a} M$. alba nodule proteins were characterized with N-terminal sequencing. Spot numbers were assigned arbitrarily and correspond to those marked in Figure 1B. A combination of proteins including those novel to the nodule and proteins likely to be bacterial in origin were chosen for analysis as well as proteins apparently present in both root and nodule. $M_{\mathrm{r}}$ and $\mathrm{pI}$ were estimated by gel migration relative to standards. When sequence was ambiguous, the alternative residues are indicated in brackets and all permutations were used for data base searching.

$\mathrm{b}$ Theoretical molecular weight and $\mathrm{pI}$ values as calculated from the amino acid sequence.

c Two independent amino acid sequences were called from the same area on the gel.
} 
Twenty-eight proteins from cultured S. meliloti 1021 cells were putatively identified on the basis of PMF matching to the $S$. meliloti data base (Tables 8 and 9). Fourteen of these proteins were down-regulated in bacteroids while one protein was up-regulated (Table 8). The down-regulated proteins showed homology to several different types of periplasmic binding proteins, proteins involved in cobalamin and cysteine biosynthesis, a protease precursor, MDH, several hypothetical proteins, and a probable $\sigma^{54}$ modulation protein that would be expected to be involved with the regulation of $\sigma^{54}$ activity. This initiation factor is responsible for the expression of the nitrogen fixation proteins (nif operon), glnA encoding GSI protein, and $d c t \mathrm{~A}$ for dicarboxylate transport. Thirteen proteins were apparently constitutively expressed in bacteroids and cultured cells (Table 9).

\section{PMF as a method of isoform identification.}

PMFs provided a quick and economical method of identifying potential protein isoforms. Of the 400 bacterial proteins examined, $10 \%$ were clearly isoforms since they gave near identical PMF patterns (not shown). Protein isoforms often formed a closely bunched horizontal train and, less commonly, a vertical train. Examples of isoforms are indicated by the boxed areas in Figure 2A. Clear isoforms of the PII protein, the chaperone GroEL, glutamine synthetase (GS), 30S ribosomal protein, heat-shock proteins and NifH were identified in either the cultured state or in the bacteroid. In some cases, isoforms of particular proteins were positioned near to each other but had significantly different molecular masses. An example of this is indicated in the black, circled area in Figure 2A.

\section{DISCUSSION}

Differential display of proteins with 2-DE has facilitated the analysis of the contribution of both symbiotic partners to the proteins present in the nodule. The two different postseparation techniques of $\mathrm{N}$-terminal sequencing and MALDITOF MS PMF matching were used to assign putative identity to proteins of interest and have provided information for over 100 proteins from the bacterium and the plant. The magnitude of the alteration in bacterial metabolism in the change from the cultured (in vitro) to the symbiotic state was demonstrated by the up-regulation of over 130 proteins in the bacteroid and by the down-regulation of at least 350 proteins found in the cultured state. This represents changes in nearly $20 \%$ of the observable rhizobial proteome and a major proportion of the

Table 2. Peptide mass fingerprint (PMF) matching of Sinorhizobium meliloti proteins isolated from bacteroids and present in both bacteroids and cultured cells ${ }^{\mathrm{a}}$

\begin{tabular}{|c|c|c|c|c|c|c|c|}
\hline \multirow{2}{*}{\multicolumn{2}{|c|}{ Protein characteristics }} & \multicolumn{6}{|c|}{ Characteristics of matching protein from data base } \\
\hline & & \multirow{2}{*}{$\begin{array}{l}\text { No. peptide } \\
\text { matches / } \\
\text { no. PMFs }\end{array}$} & \multirow{2}{*}{$\begin{array}{c}\text { Sequence } \\
\text { coverage } \\
(\%)^{\mathbf{b}}\end{array}$} & \multirow[b]{2}{*}{ Protein match } & \multirow[b]{2}{*}{ Organism } & \multirow[b]{2}{*}{ M.w./pI $I^{\mathbf{c}}$} & \multirow[b]{2}{*}{$\begin{array}{l}\text { Swiss-Prot } \\
\text { access. no. }\end{array}$} \\
\hline Spot no. & $M_{\mathrm{r}} / \mathbf{p I}$ & & & & & & \\
\hline $\mathrm{x} 74$ & $51,800 / 6.17$ & $7 / 178$ & $18.2 \%$ & Malonyl-CoA decarbox ylase & Rhizobium trifolii & $51,416 / 7.77$ & Q9ZIP6 \\
\hline $\mathrm{x} 78$ & $55,500 / 5.10$ & $15 / 119$ & $35.4 \%$ & GroEL A & S. meliloti & $57,673 / 5.00$ & P35469 \\
\hline x89 & $59,600 / 5.21$ & $17 / 123$ & $41.2 \%$ & $30 \mathrm{~S}$ ribosomal protein $\mathrm{S} 1$ & S. meliloti & $62,640 / 5.24$ & P14129 \\
\hline y15 & $73,500 / 5.86$ & $25 / 56$ & $46.9 \%$ & NAD-malic enzyme [EC 1.1.1.39] & S. meliloti & $82,865 / 5.55$ & O30807 \\
\hline y33 & $52,500 / 5.60$ & $7 / 41$ & $19.1 \%$ & Betaine aldehyde dehydrogenase [EC 1.2.1.8] & S. meliloti & $51,522 / 5.19$ & P54222 \\
\hline
\end{tabular}

${ }^{a} S$. meliloti bacteroid proteins expressed equally in cultured bacteria were characterized by matrix-assisted laser desorption/ionization time-of-flight mass spectrometry (MALDI-TOF MS) analysis. Spot numbers were assigned arbitrarily and correspond to those marked in Figure 2B. $M_{\mathrm{r}}$ and pI were estimated by gel migration relative to standards.

${ }^{\mathrm{b}}$ Indicates percentage of the data base matched protein that was made up of the matching PMFs.

${ }^{c}$ Theoretical values as calculated from the amino acid sequence.

Table 3. Peptide mass fingerprint (PMF) matching of novel or up-regulated Sinorhizobium meliloti bacteroid proteins ${ }^{\mathrm{a}}$

\begin{tabular}{|c|c|c|c|c|c|c|c|}
\hline \multirow{2}{*}{\multicolumn{2}{|c|}{ Protein characteristics }} & \multicolumn{6}{|c|}{ Characteristics of matching protein from data base } \\
\hline & & \multirow{2}{*}{$\begin{array}{c}\text { No. peptide } \\
\text { matches / } \\
\text { no. PMFs }\end{array}$} & \multirow{2}{*}{$\begin{array}{c}\text { Sequence } \\
\text { coverag } \\
\text { e }(\%)^{\mathbf{b}}\end{array}$} & \multirow[b]{2}{*}{ Protein match } & \multirow[b]{2}{*}{ Organism } & \multirow[b]{2}{*}{ M.w./pI ${ }^{\mathbf{c}}$} & \multirow[b]{2}{*}{$\begin{array}{c}\text { Swiss-Prot } \\
\text { accession no. }^{d}\end{array}$} \\
\hline Spot no. & $M_{\mathrm{r}} / \mathbf{p I}$ & & & & & & \\
\hline a15 & $32,500 / 5.62$ & $8 / 29$ & $34.7 \%$ & $\mathrm{NifH}$, nitrogenase reductase [EC 1.18.6.1] & S. meliloti & $32,024 / 5.44$ & P00460 \\
\hline $\mathrm{a} 20$ & $37,000 / 6.02$ & $5 / 30$ & $26.6 \%$ & Malate dehydrogenase [EC 1.1.1.37] & $\begin{array}{l}\text { Rhizobium legumi- } \\
\text { nosarum (bv. viciae) }\end{array}$ & $33,590 / 5.54$ & $\mathrm{O} 33525$ \\
\hline$x 63$ & $62,300 / 4.90$ & $5 / 176$ & $11.7 \%$ & DnaK & S. meliloti & $69,072 / 4.94$ & P42374 \\
\hline $\mathrm{x} 67$ & $51,500 / 5.50$ & $10 / 148$ & $25.4 \%$ & $\begin{array}{l}\text { NifD, nitrogenase molybdenum-iron } \\
\text { protein alpha chain }[\text { EC } 1.18 .6 .1]\end{array}$ & $\begin{array}{l}\text { Rhizobium sp. strain } \\
\text { NGR234 }\end{array}$ & $56,944 / 5.52$ & P19066 0.5 Da \\
\hline $\mathrm{x} 70$ & $32,500 / 5.75$ & $12 / 160$ & $25.9 \%$ & NifH & S. meliloti & $32,024 / 5.44$ & P00460 \\
\hline $\mathrm{x} 71$ & $32,600 / 5.86$ & $11 / 175$ & $37 \%$ & $\mathrm{NifH}$ & S. meliloti & $32,024 / 5.44$ & P00460 0.5 Da \\
\hline $\mathrm{x} 94$ & $35,600 / 6.08$ & $12 / 202$ & $48.5 \%$ & Alcohol dehydrogenase [EC 1.1.1.1] & S. meliloti & $36,235 / 5.68$ & O31186 \\
\hline y21 & $33,900 / 5.92$ & $11 / 35$ & $35.7 \%$ & $\mathrm{NifH}$ & S. meliloti & $32,024 / 5.44$ & P00460 \\
\hline
\end{tabular}

${ }^{a} S$. meliloti bacteroid proteins were characterized by matrix-assisted laser desorption/ionization time-of-flight mass spectrometry (MALDI-TOF MS) analysis. Spot numbers were assigned arbitrarily and correspond to those marked in Figure $2 \mathrm{~B} . M_{\mathrm{r}}$ and pI were estimated by gel migration relative to standards. "a" spots were cut from polyvinyl difluoride (PVDF) membrane while all other spots were taken from colloidal Coomassie-stained gels.

${ }^{\mathrm{b}}$ Indicates percentage of the data base matched protein that was made up of the matching PMFs.

${ }^{c}$ Theoretical values as calculated from the amino acid sequence.

${ }^{\mathrm{d}}$ Data base searches were done with a mass tolerance of \pm 0.1 Da unless otherwise indicated. 
abundant cellular proteins. However, changes in protein levels alone do not imply changes in function, as many enzymes, for example, are regulated by post-translational modifications. It is possible that a post-translational modification, such as phosphorylation, may change in-gel migration of a protein spot such that a protein classified as down-regulated may in fact still be present elsewhere on the gel. Identification of such cases will be possible once a comprehensive analysis of the entire proteome is carried out.

$\mathrm{N}$-terminal sequencing identified a mixture of plant and bacterial proteins among those proteins found in the nodule. While some of the proteins in nodules were shown to be bac- terial in origin, the origin of other nodule-specific proteins (Fig. 1B) could not be predicted by gel observation alone. These proteins may represent abundant nodule proteins of plant origin such as the late nodulin, leghemoglobin, which was identified within the nodule. The 2-DE migration pattern showed multiple leghemoglobin isoforms that correlate well with the eight isoforms of leghemoglobin identified in effective M. alba nodules by Utrup and Norris (1996) with immunoprecipitation. The absence of leghemoglobin and the lack of plant protein matches to the bacteroid sample are indicative of the purity of the bacteroid preparation. However, the presence of plant proteins in the bacteroid preparation

Table 4. Peptide mass fingerprint (PMF) matching of proteins from cultured Sinorhizobium meliloti cells and also present in bacteroids

\begin{tabular}{|c|c|c|c|c|c|c|c|}
\hline \multirow{2}{*}{\multicolumn{2}{|c|}{ Protein characteristics }} & \multicolumn{6}{|c|}{ Characteristics of matching protein from data base } \\
\hline & & \multirow{2}{*}{$\begin{array}{l}\text { No. peptide } \\
\text { matches / } \\
\text { no. PMFs }\end{array}$} & \multirow{2}{*}{$\begin{array}{c}\text { Sequence } \\
\text { coverage } \\
(\%)^{\mathbf{b}}\end{array}$} & \multirow[b]{2}{*}{ Protein match } & \multirow[b]{2}{*}{ Organism } & \multirow[b]{2}{*}{ M.w./pI ${ }^{c}$} & \multirow[b]{2}{*}{$\begin{array}{l}\text { Swiss-Pro } \\
\text { access. no. }\end{array}$} \\
\hline Spot no. & $M_{\mathrm{r}} / \mathbf{p I}$ & & & & & & \\
\hline $\mathrm{y} 41$ & $53,700 / 5.40$ & $17 / 61$ & $44.5 \%$ & 60-kDa chaperonin, $\mathrm{C}$ (GroEL C) & S. meliloti & $58,101 / 5.41$ & P35471 \\
\hline y77 & $74,100 / 5.45$ & $11 / 57$ & $24.3 \%$ & Elongation factor $\mathrm{G}$ & Agrobacterium tumefaciens & $78,045 / 5.13$ & P70782 \\
\hline y78 & $75,000 / 5.41$ & $9 / 62$ & $21.6 \%$ & Elongation factor $\mathrm{G}$ & A. tumefaciens & $78,045 / 5.13$ & P70782 \\
\hline z56 & $60,700 / 5.25$ & $7 / 19$ & $16.5 \%$ & $30 \mathrm{~S}$ ribosomal protein $\mathrm{S} 1$ & S. meliloti & $62,640 / 5.24$ & P14129 \\
\hline z57 & $60,400 / 5.21$ & $11 / 32$ & $28.7 \%$ & $30 \mathrm{~S}$ ribosomal protein $\mathrm{S} 1$ & S. meliloti & $62,640 / 5.24$ & P14129 \\
\hline $\mathrm{z} 58$ & $60,700 / 5.17$ & $9 / 26$ & $21.0 \%$ & 30 S ribosomal protein $\mathrm{S} 1$ & S. meliloti & $62,640 / 5.24$ & P14129 \\
\hline z88 & $54,600 / 5.33$ & $5 / 16$ & $15.9 \%$ & GroEL C & S. meliloti & $58,101 / 5.41$ & P35471 \\
\hline $1-20$ & $20,800 / 4.88$ & $5 / 23$ & $33.5 \%$ & $\begin{array}{l}\text { Transcription elongation factor } \\
\text { homologue }\end{array}$ & Rhizobium leguminosarum & $17,445 / 4.88$ & O68546 \\
\hline $1-24$ & $13,000 / 5.34$ & $5 / 21$ & $55.4 \%$ & GroES C & S. meliloti & $11,188 / 5.87$ & P35474 \\
\hline $1-27$ & $12,400 / 5.41$ & $6 / 20$ & $65.2 \%$ & Nitrogen regulatory protein PII & S. meliloti & $12,281 / 5.26$ & Q52905 \\
\hline $2-13$ & $36,400 / 5.79$ & $8 / 20$ & $37.4 \%$ & Alcohol dehydrogenase [EC 1.1.1.1] & S. meliloti & $36,235 / 5.68$ & O31186 \\
\hline $2-18$ & $43,200 / 5.42$ & $5 / 20$ & $25.8 \%$ & Elongation factor TU (EF-TU) & A. tumefaciens & $42,627 / 5.18$ & P75022 \\
\hline
\end{tabular}

${ }^{a}$ Proteins from $S$. meliloti grown in culture and equally expressed in bacteroids were characterized by matrix-assisted laser desorption/ionization timeof-flight mass spectrometry (MALDI-TOF MS) analysis. Spot numbers were assigned arbitrarily and correspond to those marked in Figure $2 \mathrm{~A}$. $M_{\mathrm{r}}$ and pI were estimated by gel migration relative to standards.

${ }^{\mathrm{b}}$ Indicates percentage of the data base matched protein that was made up of the matching PMFs.

${ }^{c}$ Theoretical values as calculated from the amino acid sequence.

Table 5. Peptide mass fingerprint (PMF) matching of proteins from cultured Sinorhizobium meliloti cells that were down-regulated in the bacteroid ${ }^{\mathrm{a}}$

\begin{tabular}{|c|c|c|c|c|c|c|c|}
\hline \multirow{2}{*}{\multicolumn{2}{|c|}{ Protein characteristics }} & \multicolumn{6}{|c|}{ Characteristics of protein from data base } \\
\hline & & \multirow{2}{*}{$\begin{array}{l}\text { No. peptide } \\
\text { matches / } \\
\text { no. PMFs }\end{array}$} & \multirow{2}{*}{$\begin{array}{l}\text { Sequence } \\
\text { coverage } \\
(\%)^{\mathbf{b}}\end{array}$} & \multirow[b]{2}{*}{ Protein match } & \multirow[b]{2}{*}{ Organism } & \multirow[b]{2}{*}{ M.w./pI $\mathbf{c}^{\mathbf{c}}$} & \multirow[b]{2}{*}{$\begin{array}{l}\text { Swiss-Pro } \\
\text { access. no. }\end{array}$} \\
\hline Spot no. & $M_{\mathrm{r}} / \mathbf{p I}$ & & & & & & \\
\hline $\mathrm{b} 25$ & $36,900 / 6.17$ & $6 / 25$ & $23.2 \%$ & Glutamine synthetase [EC 6.3.1.2] (fragment) & $\begin{array}{l}\text { Rhizobium sp. strain } \\
\text { USDA } 1177\end{array}$ & $\begin{array}{l}32,614 / 5.58 \\
\text { (fragment) }\end{array}$ & Q9Z3J6 \\
\hline b26 & $35,600 / 6.18$ & $9 / 30$ & $43.7 \%$ & Glutamine synthetase [EC 6.3.1.2] (fragment) & $\begin{array}{l}\text { Rhizobium sp. strain } \\
\text { USDA } 1177\end{array}$ & $\begin{array}{l}32,614 / 5.58 \\
\text { (fragment) }\end{array}$ & Q9Z3J6 \\
\hline b27 & $36,500 / 6.07$ & $6 / 46$ & $33.1 \%$ & Malate dehydrogenase [EC 1.1.1.37] & $\begin{array}{l}\text { R. leguminosarum } \\
\text { bv. (viciae) }\end{array}$ & $33,590 / 5.54$ & O33525 \\
\hline $\mathrm{b} 40$ & $34,500 / 5.81$ & $6 / 15$ & $22.3 \%$ & UDP-glucose 4-epimerase [EC 5.1.3.2] & S. meliloti & $36,113 / 5.50$ & P26503 \\
\hline y70 & $28,200 / 5.27$ & $6 / 35$ & $27.0 \%$ & Survival protein SURE & S. meliloti & $27,772 / 5.17$ & O08248 \\
\hline y92 & $32,300 / 4.79$ & $8 / 59$ & $32.8 \%$ & Putative periplasmic iron-binding protein & S. meliloti & $34,055 / 4.83$ & Q9Z3S7 \\
\hline z9 & $65,800 / 5.24$ & $14 / 73$ & $31.7 \%$ & Cell division protein $\mathrm{ftsZ}$ homologue 1 & S. meliloti & $62,975 / 5.06$ & P30327 \\
\hline z19 & $28,300 / 4.65$ & $8 / 30$ & $46.1 \%$ & Chain 1: PhoD & S. meliloti & $29,897 / 4.71$ & Q52907 \\
\hline $1-26$ & $11,500 / 5.37$ & $5 / 20$ & $57.1 \%$ & Nitrogen regulatory protein PII & S. meliloti & $12,281 / 5.26$ & Q52905 \\
\hline $1-32$ & $11,500 / 6.22$ & $5 / 20$ & $79.0 \%$ & Urease gamma subunit [EC 3.5.1.5] & S. meliloti & $11,128 / 5.77$ & P42887 \\
\hline $1-52$ & $26,400 / 6.47$ & $6 / 17$ & $41.1 \%$ & Acetoacetyl-CoA reductase [EC 1.1.1.36] & S. meliloti & $25,370 / 6.15$ & P50205 \\
\hline $1-53$ & $27,700 / 6.48$ & $7 / 17$ & $41.5 \%$ & 3-hydroxybutyrate dehydrogenase [EC 1.1.1.30] & S. meliloti & $27,179 / 6.07$ & O86034 \\
\hline $2-19$ & $49,000 / 5.44$ & $5 / 22$ & $20.3 \%$ & Glutamine synthetase I [EC 6.3.1.2] & S. meliloti & $52,035 / 5.20$ & Q59747 \\
\hline $2-73$ & $55,100 / 5.93$ & $10 / 18$ & $34.0 \%$ & $\begin{array}{l}\text { Phosphoenol pyruvate carboxykinase (ATP) [EC } \\
\text { 4.1.1.49] }\end{array}$ & S. meliloti & $58,120 / 5.57$ & P43085 \\
\hline
\end{tabular}

${ }^{a}$ Proteins from S. meliloti cells grown in culture were characterized by MALDI-TOF MS analysis. Spot numbers were assigned arbitrarily and correspond to those marked in Figure $2 \mathrm{~A} . M_{\mathrm{r}}$ and $\mathrm{p} I$ were estimated by gel migration relative to standards. "b" proteins were taken from polyvinylidene difluoride (PVDF) blots while the other spots were taken from colloidal Coomassie-stained gels.

${ }^{\mathrm{b}}$ Indicates percentage of the data base matched protein that was made up of the matching PMFs.

c Theoretical values as calculated from the amino acid sequence. 
cannot be discounted because of the reduced sensitivity of cross-species matching when considering PMF matching alone (Cordwell et al. 1995). NifK and NifH, which are components of the bacterial nitrogenase enzyme complex, were also identified and their relative abundances in bacteroid and nodule preparations were similar (Figs. 1B and 2B and Table 1).

\section{Proteins involved in nitrogen metabolism.}

Several proteins involved in nitrogen metabolism and regulation were identified on the basis of PMF homology. Two forms of the PII protein were identified with a reduction in one form at the protein level found in the bacteroid. Although clear differences in molecular mass and pI are observed, the spectra for the two proteins (spots 1-26 and 1-27, Fig. 2A) were very similar (spectra not shown). In S. meliloti, the PII protein is involved in both nitrogen metabolism and nodule development (Arcondéguy et al. 1997). This intracellular signal transducer is required in the free-living state and is involved in the regulation of GS activity. PII is regulated by feedback inhibition by glutamine, covalent modification, namely, uridinylation and regulation at the protein synthesis level. Under limited nitrogen conditions, PII is uridylylated and as a result GS, which is involved in ammonium assimila- tion, is activated, while under high nitrogen conditions the reverse occurs. Thus, the PII protein may be an example of the different functional activities and roles of post-translationally modified protein isoforms. However, it was not possible to determine if these two proteins were post-translationally modified isoforms (uridinylated and non-uridinylated) from the spectra with the FindMod tool available from ExPASy.

The down-regulation of a PII isoform is consistent with the observation that three proteins with homology to GS were also found to be down-regulated in the bacteroid. GS is generally important to nitrogen metabolism since glutamine is a precursor of many other metabolites and is part of the ammonium assimilation and amino acid biosynthesis pathways. Although S. meliloti contains three forms of GS, named GSI, GSII, and GSIII (de Bruijn et al. 1989), regulation of their expression and function is complex and dependent upon transcriptional and post-translational controls. Arcondéguy et al. (1996) showed that the activity of GSI was regulated by adenylation and that there was a reduction in the amount of GS protein present in bacteroid cells. GSII is not expressed in S. meliloti bacteroids (de Bruijn et al. 1989) and GSIII is not normally expressed in the presence of GSI or GSII (Shatters et al. 1993). Swiss-Prot predicts the molecular weights for the three

Table 6. Putative identity of Sinorhizobium meliloti 1021 bacteroid proteins present at altered levels, compared with cultured cells ${ }^{\mathrm{a}}$

\begin{tabular}{|c|c|c|c|c|c|c|c|}
\hline \multicolumn{3}{|c|}{ Peptide characteristics } & \multicolumn{2}{|c|}{ MassLynx results } & \multicolumn{3}{|c|}{ BLAST search results } \\
\hline $\begin{array}{l}\text { Spot } \\
\text { no. }\end{array}$ & $M_{\mathrm{r}} / \mathbf{p I}$ & Status $^{\mathrm{b}}$ & $\begin{array}{c}\text { Matches / missed cleavages } \\
\text { (sequence coverage [\%]) }\end{array}$ & Clone & Protein & $\begin{array}{l}\text { Identity } \\
(\%)\end{array}$ & $\begin{array}{l}\text { Hit features (\% query / } \\
\% \text { clone covered) }\end{array}$ \\
\hline a17 & $17,900 / 6.24$ & Novel & $7 / 4(45)$ & 491005A07.x1 & Small heat shock protein & 45 & $79 / 70$ \\
\hline $\mathrm{a} 20$ & $37,000 / 6.02$ & Novel & $9 / 4(58)$ & 423012D12.x1 & Hypothetical & 90 & $\begin{array}{c}85 / 100 \\
\text { Malate dehydrogenase } \\
\text { Rhizobium leguminosarum }\end{array}$ \\
\hline $\mathrm{x} 77$ & $17,800 / 6.53$ & Up & $7 / 4(45)$ & 491005A07.x1 & Small heat shock protein & 45 & $79 / 70$ \\
\hline y10 & $17,900 / 6.28$ & Novel & $7 / 4(45)$ & 491005A07.x1 & Small heat shock protein & 79 & $79 / 70$ \\
\hline y22 & $42,700 / 5.80$ & Up & $5 / 0(36)$ & 423037G10.x1 & Adenylosuccinate synthetase & 92 & $78 / 36$ \\
\hline
\end{tabular}

a Proteins from S. meliloti 1021 bacteroids were characterized by matrix-assisted laser desorption/ionization time-of-flight mass spectrometry (MALDITOF MS) analysis. The peptide mass fingerprints generated were used to interrogate a $1 \mathrm{X}$ S. meliloti sequence data base that had been translated in all six reading frames (see Materials and Methods). The matching putative open reading frame was then used to search an S. meliloti chromosome BLAST server. Spot numbers were assigned arbitrarily and correspond to those marked in Figure 2B. $M_{\mathrm{r}}$ and $\mathrm{pI}$ were estimated by gel migration relative to standards.

${ }^{\mathrm{b}}$ Status: Novel - novel to source, Up - up-regulated in source.

Table 7. Putative identity of Sinorhizobium meliloti 1021 bacteroid proteins constitutively expressed in cultured and bacteroid cells ${ }^{\mathrm{a}}$

\begin{tabular}{|c|c|c|c|c|c|c|c|}
\hline \multirow{2}{*}{\multicolumn{2}{|c|}{ Peptide characteristics }} & \multicolumn{2}{|c|}{ MassLynx search results } & \multicolumn{3}{|c|}{ BLAST search results } & \multirow{3}{*}{$\begin{array}{c}\begin{array}{c}\text { Swiss-Prot } \\
\text { search result }\end{array} \\
\\
\text { Protein - Organism }\end{array}$} \\
\hline & & \multirow{2}{*}{$\begin{array}{l}\text { Matches / missed } \\
\text { cleavages (seq. cov- } \\
\text { erage [\%]) }\end{array}$} & \multirow[b]{2}{*}{ Clone } & \multirow[b]{2}{*}{ Protein } & \multirow[b]{2}{*}{$\begin{array}{l}\text { Identity } \\
(\%)\end{array}$} & \multirow{2}{*}{$\begin{array}{l}\text { Hit features (\% } \\
\text { query / \% clone } \\
\text { covered) }\end{array}$} & \\
\hline Spot no. & $M_{\mathrm{r}} / \mathbf{p I}$ & & & & & & \\
\hline a19 & $24,000 / 4.85$ & $5 / 0(48)$ & 423110A01.x1 & Hypothetical & 91 & $100 / 79$ & \\
\hline$x 64$ & $53,500 / 4.96$ & $9 / 1(51)$ & 423112A04.x1 & $\begin{array}{l}\text { Glutamyl-tRNA amidotrans- } \\
\text { ferase subunit B }\end{array}$ & 92 & $100 / 46$ & \\
\hline x89 & $60,200 / 5.21$ & $7 / 2(44)$ & 423121D08.x1 & $30 \mathrm{~S}$ ribosomal protein $\mathrm{S} 1$ & 93 & $98 / 39$ & $\begin{array}{l}\text { 30S ribosomal pro- } \\
\text { tein } \mathrm{S} 1 S . \text { meliloti }\end{array}$ \\
\hline y2 & $60,800 / 5.60$ & $5 / 0(40)$ & 423069D10.x1 & Aminopeptidase $\mathrm{P}$ & 82 & $98 / 31$ & \\
\hline y9 & $47,200 / 6.43$ & $6 / 2(40)$ & 423087H05.x1 & Adenylosuccinate lyase & 87 & $98 / 53$ & \\
\hline y14 & $80,100 / 5.78$ & $7 / 1(51)$ & 423047G06.x1 & ATP-dependent protease (HSP) & 84 & $97 / 22$ & \\
\hline y15 & $73,500 / 5.86$ & $6 / 2(31)$ & 423110G01.x1 & NAD-malic enzyme & 93 & $100 / 29$ & $\begin{array}{l}\text { NAD-malic enzyme } \\
\text { S. meliloti }\end{array}$ \\
\hline y20 & $19,600 / 5.85$ & $5 / 0(73)$ & 423078E07.x1 & Single-strand binding protein & 51 & $100 / 62$ & \\
\hline
\end{tabular}

${ }^{a}$ Proteins from S. meliloti 1021 bacteroids were characterized by matrix-assisted laser desorption/ionization time-of-flight mass spectrometry (MALDITOF MS) analysis. The peptide mass fingerprints of the proteins generated were used to interrogate a 1X S. meliloti sequence data base that had been translated in all six reading frames (see Materials and Methods). The matching putative open reading frame was then used to search an $S$. meliloti chromosome BLAST server. Spot numbers were assigned arbitrarily and correspond to those marked in Figure $2 \mathrm{~B}$. $M_{\mathrm{r}}$ and $\mathrm{pI}$ were estimated by gel migration relative to standards. 
different forms of $S$. meliloti GSs as 52,035, 36,966, and 48,481 for GSI, GSII, and GSIII, respectively. Therefore, it seems likely that spot 2-19 is GSI while the other two spots (b25 and b26) are GSII, based on molecular mass similarities.

In bacteroids, the gamma subunit of urease, which as part of the urea cycle catalyzes the conversion of urea to $\mathrm{NH}_{3}$, was also down-regulated, as was the urea-amide binding protein, rm1. The down-regulation of proteins involved in the uptake and metabolism of urea or other similar compounds is consistent with the shift from ammonium assimilation to ammonium export and the idea that bacteroids are nitrogen proficient (Kahn et al. 1998).

\section{Proteins involved in carbon metabolism.}

Non-symbiotic bacteria metabolize sugars such as sucrose but evidence suggests that metabolism switches to $\mathrm{C}_{4}$ dicarboxylic acids such as malate and succinate in the nodule. As a result, it would not be surprising to see changes in the levels of proteins involved in these different parts of the carbon metabolic cycle.

Several enzymes of the TCA cycle were identified, including MDH and IDH. MDH was identified in both cultured and bacteroid forms of $S$. meliloti 1021 although the isoelectric points appeared to differ slightly. Unfortunately, because $S$. meliloti MDH is not represented in Swiss-Prot, it is difficult to tell what the difference between the two forms analyzed might be. The spectra obtained are largely identical and the FindMod tool available from ExPASy suggested that the bacteroid form may contain one methylated site while the form from cultured cells may contain four methylation sites (data not shown). However, it is not clear whether the proteins analyzed are the same but with modifications, or are actually different forms of the enzyme. IDH, which was identified in the nodule and appeared to be present in bacteroids and cultured $S$. meliloti cells, may act as the source of reductant for nitrogen fixation, as IDH activity in bacteroids isolated from $P$. sativum nodules was found to be highest when nitrogen fixation was at a maximum (Kurz and LaRue 1977).

A protein with homology to NAD-dependent ME was also identified. $\mathrm{ME}$ catalyzes the formation of pyruvate from malate, a $\mathrm{C}_{4}$-dicarboxylic acid. $\mathrm{C}_{4}$-dicarboxylic acids are generally thought to be the reduced carbon source supplied to the bacteroids by the plant (Day and Copeland 1991). Both NADP- and NAD-dependent forms of ME have been identified in $S$. meliloti, although NADP-dependent ME is not required for nitrogen fixation (Driscoll and Finan 1996). The NAD-dependent form of ME, which we identified from $S$. meliloti bacteroids, is speculated to be the more important form during nitrogen fixation. Day and Copeland (1991) speculated that, together with MDH, NAD-ME could provide an effective means of generating the acetyl-CoA and oxaloacetate required for the TCA cycle.

Two proteins with PMF homology to ADH were also identified. This enzyme catalyzes the conversion of aldehydes or ketones into alcohol under anaerobic conditions, generating $\mathrm{NAD}^{+}$required for glycolysis. Interestingly, one protein (spot 2-13) appeared to be present in both the cultured and bacteroid forms of the bacteria, while another (spot x94) appeared to be

Table 8. Putative identity of proteins from cultured Sinorhizobium meliloti 1021 cells present at altered levels, compared with bacteroids ${ }^{\mathrm{a}}$

\begin{tabular}{|c|c|c|c|c|c|c|c|c|}
\hline \multirow{2}{*}{\multicolumn{3}{|c|}{ Peptide characteristics }} & \multirow{3}{*}{$\begin{array}{c}\text { MassLyn } \\
\begin{array}{c}\text { Matches / missed } \\
\text { cleavages (seq. } \\
\text { coverage [\%]) }\end{array} \\
\end{array}$} & \multirow[t]{3}{*}{ results } & \multicolumn{3}{|c|}{ BLAST search results } & \multirow{3}{*}{$\begin{array}{c}\begin{array}{c}\text { Swiss-Prot } \\
\text { search result }\end{array} \\
\text { Protein - Organism }\end{array}$} \\
\hline & & & & & \multirow[b]{2}{*}{ Protein } & \multirow[b]{2}{*}{$\begin{array}{l}\text { Identity } \\
(\%)\end{array}$} & \multirow{2}{*}{$\begin{array}{l}\text { Hit features } \\
\text { (\% query / \% } \\
\text { clone covered) }\end{array}$} & \\
\hline Spot no. & $M_{\mathrm{r}} / \mathbf{p I}$ & Status $^{\mathrm{b}}$ & & & & & & \\
\hline b4 & $17,500 / 5.32$ & Down & $8 / 4(55)$ & 423112F07.x1 & Hypothetical & 90 & $85 / 100$ & \\
\hline b27 & $36,500 / 6.07$ & Down & $5 / 0(63)$ & 423012D12.x1 & Malate dehydrogenase & 81 & $100 / 48$ & $\begin{array}{l}\text { Malate dehydroge- } \\
\text { nase } R \text {. legumi- } \\
\text { nosarum }\end{array}$ \\
\hline y68 & $34,400 / 5.38$ & Down & $6 / 0(41)$ & 423056B01.x1 & $\begin{array}{l}\text { O-acetylserine sulfhy- } \\
\text { drylase A }\end{array}$ & 95 & $97 / 70$ & \\
\hline y87 & $35,500 / 5.91$ & Down & $6 / 0(32)$ & 423019B02.x2 & $\begin{array}{l}\text { Cobalamin biosynthesis } \\
\text { (COBS) }\end{array}$ & 99 & $99 / 63$ & \\
\hline y88 & $34,100 / 5.94$ & Down & $6 / 0(56)$ & 423036G01.x1 & Hypothetical & 32 & $82 / 44$ & \\
\hline $\mathrm{z} 10$ & $46,900 / 4.79$ & Down & $7 / 0(52)$ & 423085D04.x1 & $\begin{array}{l}\text { Periplasmic sorbitol- } \\
\text { binding protein }\end{array}$ & 100 & $100 / 47$ & \\
\hline $\mathrm{z} 20$ & $40,900 / 4.88$ & Down & $8 / 1(60)$ & 423085D04.x1 & $\begin{array}{l}\text { Periplasmic sorbitol- } \\
\text { binding protein }\end{array}$ & 100 & $100 / 47$ & \\
\hline $\mathrm{z} 35$ & $58,000 / 5.71$ & Down & $5 / 1(30)$ & 423106B05.x1 & $\begin{array}{l}\text { Periplasmic dipeptide- } \\
\text { binding protein }\end{array}$ & 26 & $96 / 40$ & \\
\hline z93 & $58,000 / 4.78$ & Down & $5 / 1(32)$ & 423001E01.x1 & Protease precursor & 79 & $96 / 38$ & \\
\hline $1-5$ & $43,400 / 4.42$ & Down & $6 / 2(60)$ & 423074B12.x1 & $\begin{array}{l}\mathrm{ABC} \text { transporter peri- } \\
\text { plasmic-binding protein }\end{array}$ & 98 & $99 / 50$ & \\
\hline $1-48$ & $19,700 / 6.53$ & Up & $7 / 4(45)$ & 491005A07.x1 & Small heat shock protein & 45 & $79 / 70$ & \\
\hline $2-60$ & $41,400 / 6.26$ & Down & $6 / 0(39)$ & 423110C09.x1 & Hypothetical & 23 & $76 / 61$ & \\
\hline $2-94$ & $27,200 / 5.88$ & Down & $5 / 1(40)$ & 423043D06.x1 & $\begin{array}{l}\text { Probably } \sigma^{54} \text { modula- } \\
\text { tion protein }\end{array}$ & 93 & $100 / 91$ & \\
\hline
\end{tabular}

\footnotetext{
${ }^{\text {a }}$ Proteins from S. meliloti 1021 cells grown in culture were characterized by matrix-assisted laser desorption/ionization time-of-flight mass spectrometry (MALDI-TOF MS) analysis. The peptide mass fingerprints of the proteins were generated and used to interrogate a 1X S. meliloti sequence data base that had been translated in all six reading frames (see Materials and Methods). The matching putative open reading frame was then used to search an $S$. meliloti chromosome BLAST server. Spot numbers were assigned arbitrarily and correspond to those marked in Figure 2A. $M_{\mathrm{r}}$ and pI were estimated by gel migration relative to standards.

${ }^{\mathrm{b}}$ Status: Down - down-regulated in source, Up - up-regulated in source.
} 
up-regulated in the bacteroid. These proteins had almost identical PMF spectra (not shown), but it is unclear from the available data what post-translational modifications may be present. In S. meliloti, the gene encoding ADH ( $a d h A)$ has been mapped to the 1.4-Mb megaplasmid, pSyma (Barloy-Hubler et al. 2000). However, Willis and Walker (1998) found that $S$. meliloti adhA mutants retained some ADH activity, suggesting that ADH is encoded by more than one gene. This may account for our observation of two proteins with homology to $\mathrm{ADH}$.

Two proteins with homology to enzymes involved in polyhydroxybutyrate (PHB) synthesis, acetoacyl-CoA reductase, and 3hydroxybutyrate dehydrogenase, were down-regulated in the bacteroid. PHBs act as a carbon sink (Walshaw et al. 1997) and can account for up to $98 \%$ of lipids extracted from rhizobia. Although the presence of PHB varies in the bacteroids of different rhizobia species, the down-regulation of the enzyme levels found here agrees with the observation that wild-type $S$. meliloti bacteroids do not contain PHB (Kahn et al. 1998).

\section{Heat shock and cell division proteins.}

Although changes in levels of proteins with homology to several heat-shock proteins and a cell division protein were identified, these proteins are probably altered as a consequence of symbiosis and not as a cause. Barloy-Hubler et al. (2000) found that these types of proteins, with the exception of those encoded by groESLa, did not appear to be encoded by pSyma on which genes involved in nodulation and nitrogen fixation are located.
The chaperonin DnaK, which is the major prokaryotic form of the heat-shock protein, was found to be up-regulated in the bacteroid. This protein is required for correct protein folding and is induced under stress conditions (Münchbach et al. 1999). Several small heat-shock proteins (spots 14, 1-48, a17, $\mathrm{x} 77$, and $\mathrm{y} 10$ ) were also up-regulated or induced in nodules. The process of infection and adaptation to the endophytic environment could be a stressful event for the bacteria (Brewin 1998) or, alternatively, these proteins could be involved in the folding and stabilization of many of the nodule-specific proteins, as has been found for NodD by GroEL C (Ogawa and Long 1995). The up-regulated or induced expression of DnaK and other heat-shock proteins in the bacteroid is consistent with this hypothesis.

Among bacteroid proteins that were apparently downregulated was a cell division protein, ftsZ homologue 1 , that putatively binds to and hydrolyzes GTP and is essential to the cell division process (Margolin et al. 1991). S. meliloti contains two fts $Z$ homologues that both map to the chromosome, but although the second homologue lacks the carboxy-terminal region conserved in other ftsZ proteins, overproduction of either inhibits cell division (Margolin and Long 1994). Overproduction of ftsZ resulted in branched and swollen cells, suggesting that these are the ways by which cell mass is increased in the absence of cell division (Latch and Margolin 1997). Although this protein appeared to be present at lower levels in the bacteroid than in cultured cells, we cannot infer what division status the bacteroids are in (i.e., lower ftsZ levels do not necessarily mean

Table 9. Putative identity of proteins from cultured Sinorhizobium meliloti 1021 cells constitutively expressed in cultured and bacteroid cells ${ }^{\mathrm{a}}$

\begin{tabular}{|c|c|c|c|c|c|c|c|}
\hline \multirow{2}{*}{\multicolumn{2}{|c|}{ Peptide characteristics }} & \multicolumn{2}{|c|}{ MassLynx results } & \multicolumn{3}{|c|}{ BLAST search results } & \multirow{3}{*}{$\begin{array}{c}\begin{array}{c}\text { Swiss-Prot } \\
\text { search result }\end{array} \\
\text { Protein - } \\
\text { Organism }\end{array}$} \\
\hline & & \multirow{2}{*}{$\begin{array}{l}\text { Matches / missed } \\
\text { cleavages (seq. } \\
\text { coverage [\%]) }\end{array}$} & \multirow[b]{2}{*}{ Clone } & \multirow[b]{2}{*}{ Protein } & \multirow[b]{2}{*}{$\begin{array}{l}\text { Identity } \\
(\%)\end{array}$} & \multirow{2}{*}{$\begin{array}{l}\text { Hit features (\% } \\
\text { query / \% } \\
\text { clone covered) }\end{array}$} & \\
\hline Spot no. & $M_{\mathrm{r}} / \mathbf{p I}$ & & & & & & \\
\hline $\mathrm{y} 72$ & $31,000 / 5.23$ & $6 / 0(45)$ & $423123 \mathrm{G} 06 . x 2$ & Hypothetical & 87 & $100 / 61$ & \\
\hline y91 & $32,500 / 4.84$ & $8 / 3(53)$ & 423051A08.x1 & Hypothetical & 26 & $95 / 53$ & \\
\hline $\mathrm{z} 54$ & $52,700 / 4.96$ & $7 / 0(45)$ & 423021E03.x1 & $\begin{array}{l}\text { Glutamyl-tRNA amidotrans- } \\
\text { ferase subunit B }\end{array}$ & 90 & $100 / 42$ & \\
\hline z56 & $60,700 / 5.26$ & $6 / 1(43)$ & 423121D08.x1 & $30 \mathrm{~S}$ ribosomal protein $\mathrm{S} 1$ & 93 & $98 / 39$ & $\begin{array}{c}\text { 30S ribosomal } \\
\text { protein S1 } \\
\text { S.meliloti }\end{array}$ \\
\hline z57 & $60,400 / 5.21$ & $8 / 2(49)$ & 423121D08.x1 & $30 \mathrm{~S}$ ribosomal protein $\mathrm{S} 1$ & 93 & $98 / 39$ & $\begin{array}{l}\text { 30S ribosomal } \\
\text { protein S1 } \\
\text { S. meliloti }\end{array}$ \\
\hline $\mathrm{z} 58$ & $60,700 / 5.17$ & $5 / 1(35)$ & 423121D08.x1 & 30S ribosomal protein $\mathrm{S} 1$ & 93 & $98 / 39$ & $\begin{array}{l}\text { 30S ribosomal } \\
\text { protein S1 } \\
\text { S. meliloti }\end{array}$ \\
\hline z59 & $45,500 / 5.16$ & $6 / 1$ & 423085E05.x1 & Histidinol dehydrog enase & 100 & $97 / 48$ & \\
\hline z89 & $53,200 / 5.31$ & $6 / 0(42)$ & 491008F01.x1 & $\begin{array}{l}\text { Glutamyl-tRNA amidotrans- } \\
\text { ferase subunit B }\end{array}$ & 91 & $100 / 48$ & \\
\hline 1.24 & $13,000 / 5.34$ & $7 / 3(54)$ & 423063C06.x1 & $10 \mathrm{kDa}$ chaperonin A & 83 & $63 / 91$ & $\begin{array}{l}\text { GroES C } \\
\text { S. meliloti }\end{array}$ \\
\hline 1.49 & $22,900 / 6.62$ & 7 / 1 (74) & 423111D06.x2 & $\begin{array}{c}\text { Transcription anti-termination } \\
\text { protein }\end{array}$ & 91 & $100 / 80$ & \\
\hline 1.57 & $27,600 / 6.27$ & $6 / 0(46)$ & 423097C03.x1 & Oxidoreductase & 31 & $98 / 86$ & \\
\hline 1.73 & $20,900 / 5.83$ & $6 / 1(74)$ & 423078E07.x1 & Single-strand binding protein & 51 & $100 / 62$ & \\
\hline 2.20 & $48,300 / 5.39$ & $8 / 2(81)$ & $423078 \mathrm{C} 03 . \mathrm{x} 1$ & Mannitol 2-dehydrogenase & 98 & $98 / 39$ & \\
\hline 3.50 & $45,000 / 5.51$ & $6 / 1(40)$ & 423034B11.x1 & Hypothetical & 91 & $98 / 42$ & \\
\hline 3.57 & $30,100 / 6.37$ & $8 / 2(50)$ & 423047H05.x1 & Hypothetical & 99 & $100 / 69$ & \\
\hline
\end{tabular}

${ }^{a}$ Proteins from $S$. meliloti 1021 cells grown in culture were characterized by matrix-assisted laser desorption/ionization time-of-flight mass spectrometry (MALDI-TOF MS) analysis. The peptide mass fingerprints of the proteins generated were used to interrogate a $1 \mathrm{X} S$. meliloti sequence data base that had been translated in all six reading frames (see Materials and Methods). The matching putative open reading frame was then used to search an $S$. meliloti chromosome BLAST server. Spot numbers were assigned arbitrarily and correspond to those marked in Figure $2 \mathrm{~A}$. $M_{\mathrm{r}}$ and $\mathrm{pI}$ were estimated by gel migration relative to standards. 
that cells are not dividing). In E. coli, levels of ftsZ transcription varied with the cell cycle with levels highest at about midcycle and lowest at division (Zhou and Helmstetter 1994). Earlier, Dai and Lutkenhaus (1992) found results of varying the relative levels of $f t s Z$ and $f t s A$ that suggested that the gene products may interact, and that it may be the ratio of ftsZ to ftsA that is critical in the control of cell division.

\section{Other proteins.}

Other proteins that were down-regulated in the bacteroid included several proteins with homology to periplasmic binding proteins (Tables 5 and 8). This is consistent with the finding of Gage and Long (1998), who identified a gene with protein sequence homology to a periplasmic oligopeptide-binding protein that was differentially expressed (decreased) when $S$. meliloti became an intracellular microsymbiont. The downregulation of proteins involved in the uptake of sugars and small peptides is consistent with the shift in carbon and nitrogen metabolism outlined above.

We have also identified a protein with putative homology to a probable $\sigma^{54}$ modulation factor and have classed it as being down-regulated in the bacteroid. Ronson et al. (1987) identified a ntrA-like gene whose gene product ntrA had homology to $\sigma^{54}$ and is required for $\mathrm{C}_{4}$-dicarboxylate transport $(\operatorname{dct} A)$ and symbiotic nitrogen fixation (nifA). The down-regulation of the $\sigma^{54}$ modulation factor observed here suggests that it may work as a negative regulator and, when absent, allows the $\sigma^{54}$ transcription factor to function in gene transcription.

\section{Oxygen regulation of protein synthesis.}

During the symbiotic interaction the plant supplies the bacteroid with reduced carbon in exchange for fixed nitrogen as well as subjecting the bacteria to the changes in oxygen in the environment required for the functional activity of nitrogenase. In B. japonicum, proteins have been identified that change in expression levels as a result of the change in available oxygen concentration (Dainese-Hatt et al. 1999). Oxygen regulation could account for a proportion of the changes in protein levels observed in our gels.

\section{Estimation of the extent of post-translational modification in S. meliloti.}

MALDI-TOF MS analysis not only provided the likely identity of over $100 \mathrm{~S}$. meliloti proteins but also confirmed that about $10 \%$ of the protein species analyzed were isoforms. For example, four forms of NifH were identified among the proteins novel to the bacteroid (compared with the bacteria). $S$. meliloti contains only one copy of the nifH gene (Corbin et al. 1982) and the presence of isoforms of the NifH protein has, to our knowledge, not previously been reported. Several isoforms of elongation factor $\mathrm{G}$, the $30 \mathrm{~S}$ ribosomal protein $\mathrm{S} 1$, small heat-shock protein, GroEL, and GS were also found. The extent of protein isoforms in rhizobia has not been previously established but the estimate of $10 \%$ of proteins being isoforms is consistent with a similar estimate of $18 \%$ made for E. coli (Link et al. 1997).

Membrane and other hydrophobic proteins are probably under-represented in 2-DE gels at the present time. Therefore, nodulins located in the membrane, such as nodulin 26 , are unlikely to be identified by the method described in this paper due to their insolubility in the detergent used. However, recent advances in 2-DE technology, particularly in areas such as development of improved detergents that are compatible with 2-DE and rehydration of the isoelectric focusing strip with the protein sample to be separated, are improving the chances of observing membrane proteins (Molloy 2000). Sample enrichment and sequential extraction methods will also help to improve the range of proteins detected by 2-DE proteome methods (Molloy et al. 1998) as will use of isoelectric focusing strips that cover wide $\mathrm{pH}$ ranges separated over longer distances (Görg et al. 1999).

Adding the results of our work to previously generated matches (Guerreiro et al. 1999), we now have information about the expression of over 100 proteins from S. meliloti. With the completion of the $S$. meliloti genome data base, the data generated here will help to provide a more complete picture of events occurring within this model microsymbiont during the transition from free-living to bacteroid states. In line with similar studies in yeast, we expect that confident matches for up to $90 \%$ of the PMF entries will be made once the complete $S$. meliloti genome sequence becomes available (Shevchenko et al. 1996).

\section{MATERIALS AND METHODS}

\section{Chemicals.}

All chemicals used were of the highest obtainable grade and are outlined in Guerreiro et al. (1997). MilliQ-qualilty water (Millipore, Bedford, MA) with resistance of greater than 18 $\mathrm{M} \Omega . \mathrm{cm}$ was used throughout.

\section{Plant growth and inoculation.}

M. alba seeds were obtained as a gift from A. M. Hirsch (University of California). Seeds were scarified and then surface sterilized in $70 \% \mathrm{vol} / \mathrm{vol}$ ethanol containing a $0.5 \%$ $\mathrm{vol} / \mathrm{vol}$ Tween detergent for $5 \mathrm{~min}$ and then in commercial bleach (5\% available chlorine present as sodium hypochlorite) for $15 \mathrm{~min}$. After five rinses with sterile, distilled water, the seeds were placed on Bergensen's modified medium (BMM) plates (Bergensen 1961), covered with a thin layer of water agar $\left(0.8 \% \mathrm{wt} / \mathrm{vol}\right.$ in water), and placed at $4^{\circ} \mathrm{C}$ for $48 \mathrm{~h}$ in the dark to synchronize germination. The plates were then transferred into a $29^{\circ} \mathrm{C}$ incubator for $24 \mathrm{~h}$ in the dark to germinate. Germinated seedlings were transferred to Fåhraeus medium plates (Fåhraeus 1957) modified to contain $1.2 \mathrm{mM} \mathrm{CaCl}_{2}$ and adjusted to $\mathrm{pH}$ 7.1. Five seedlings were transferred to each plate and grown in growth chambers with a $16 \mathrm{~h}$ night / $8 \mathrm{~h}$ day cycle at $20^{\circ} \mathrm{C} / 25^{\circ} \mathrm{C}$, respectively, $60 \%$ relative humidity, and a photon flux density of $160 \mu \mathrm{mol} \mathrm{s} \mathrm{s}^{-1} \mathrm{~m}^{-2}$ with a combination of metal halide and fluorescent lighting. After 4 days, plants were inoculated at the root tip with $10 \mu \mathrm{l}$ of either $S$. meliloti 1021 grown in liquid BMM containing between $10^{5}$ and $10^{6}$ bacteria, or liquid BMM only. After 12 days, nodules or sections of mock-inoculated roots ( $2 \mathrm{~cm}$ down from site of inoculation) were harvested and immediately frozen in liquid nitrogen.

\section{Plant protein extraction.}

Total cellular protein was extracted from 500-mg samples of roots or nodules. Extraction followed the method of Kamo et al. (1995) with some modifications. The samples were ground in liquid nitrogen and precipitated with cold $\left(-20^{\circ} \mathrm{C}\right) 10 \%(\mathrm{wt} / \mathrm{vol}) \mathrm{TCA}$ in acetone containing $0.07 \%$ 
(wt/vol) dithiothreitol (DTT). After $1 \mathrm{~h}$ at $-20^{\circ} \mathrm{C}$, the sample was centrifuged at $35,000 \times g$ for $15 \mathrm{~min}$ at $4^{\circ} \mathrm{C}$ with a Sorvall SW-50.1 rotor (Du Pont, New Town, CT), which was used for all centrifugation steps. The precipitate was washed twice in acetone containing $0.07 \%$ (wt/vol) DTT with 30-min incubations at $-20^{\circ} \mathrm{C}$ and centrifugation at $12,000 \times g$ for $15 \mathrm{~min}$ at $4^{\circ} \mathrm{C}$ for each wash. The samples were lyophilized for $5 \mathrm{~min}$ and immediately resuspended in $1 \mathrm{ml}$ of lysis buffer (Guerreiro et al. 1997) by a combination of vortexing and sonication. Insoluble material was removed by centrifugation at $19,000 \times g$ for $15 \mathrm{~min}$ at $20^{\circ} \mathrm{C}$. The protein concentration of the supernatant was determined by the Bradford dye-binding assay (Bio-Rad, Hercules, CA) with bovine serum albumin as the standard.

\section{Bacterial growth, bacteroid isolation, and protein extraction.}

S. meliloti 1021 was used for all experiments and was grown at $28^{\circ} \mathrm{C}$ in BIII medium (Dazzo 1982) to early exponential phase $\left(\mathrm{OD}_{600}\right.$ of 0.32$)$. Cells were harvested and samples prepared for 2-DE (Guerreiro et al. 1997).

Bacteroids were isolated from $M$. alba nodules by the modified method of Day et al. (1989), with some additional unpublished modifications outlined here. Nodules $(1.5 \mathrm{~g}$ fresh weight per extraction) were harvested 12 days after inoculation with $S$. meliloti and rinsed in ice-cold wash buffer containing $350 \mathrm{mM}$ mannitol, $25 \mathrm{mM}$ 2-[N-morpholino]ethanesulfonic acid (MES)- $\mathrm{KOH}\left(\mathrm{pH} 7.0\right.$ ) and $3 \mathrm{mM} \mathrm{MgSO} 4.7 \mathrm{H}_{2} \mathrm{O}$. The peribacteroid units (PBUs) were isolated by the Percoll gradient method with proportional reduction in the volumes used. The 60-80\% Percoll gradient band containing large, intact PBUs was resuspended in $12 \mathrm{ml}$ of wash buffer by gentle inversion before being centrifuged in a Sorvall $\mathrm{HB}-4$ rotor $(\mathrm{Du}$ Pont, New Town, CT) for $15 \mathrm{~min}$ at $5,000 \mathrm{rpm}$ and $4{ }^{\circ} \mathrm{C}$. The supernatant was removed and the PBUs resuspended in $1 \mathrm{ml}$ of wash buffer containing the proteinase inhibitors $1 \mathrm{mM}$ phenylmethylsulfonyl fluoride (PMSF; Sigma, St. Louis, $\mathrm{MO}$ ), $5 \mu \mathrm{M}$ trans-expoxysuccinyl-L-leucylamido-(4-guanidino)butane (E64; Sigma) and $1 \mathrm{mM}$ DTT. The sample was then vigorously vortexed for $2 \mathrm{~min}$ to rupture the PBUs. The mixture was transferred to a clean Eppendorf tube and centrifuged at 5,000 rpm (Eppendorf microfuge; Brinkman Instruments, Westbury, NY) for $5 \mathrm{~min}$ at $4^{\circ} \mathrm{C}$ to pellet pure bacteroids. Protein extraction from each bacteroid pellet was done by the method given in Guerreiro et al. (1997) with $1 \mathrm{ml}$ of lysis buffer per pellet.

\section{2-DE.}

2-DE was done as previously described (Görg et al. 1995) with minor modifications (Guerreiro et al. 1997). Isoelectric focusing was done on $18 \mathrm{~cm}$, linear $\mathrm{pH} 4$ to 7, IPG strips (Amersham Pharmacia Biotech, Uppsala, Sweden). For analytical gels, an aliquot containing $100 \mu \mathrm{g}$ of protein was loaded onto each IPG strip. For preparative gels, an aliquot containing $1 \mathrm{mg}$ of protein was loaded onto each IPG strip. When multiple loadings were required, the isoelectric focusing run was restarted from the beginning after each loading.

\section{Image processing and analysis.}

Proteins on analytical 2-DE gels were visualized by silver staining (Rabilloud 1992) with the addition of $2.5 \mathrm{mM} \mathrm{N}$-[2- hydroxyethyl]piperazine- $N^{\prime}$-[2-ethanesulfonic acid], hemisodium salt (HEPES; Research Organic, Cleveland, OH) buffer to the silver nitrate solution (Rabilloud et al. 1994). The images were digitized at 600 dpi with a UMAX PS-2400X lamp scanner run under Photoshop 3.0 (Adobe, Mountain View, CA). The resulting images were transferred into the UNIX environment of an SUNW, Ultra 5 station (Sun Microsystems, Mountain View, CA) for analysis. With MELANIE 2.3 image analysis software (Bio-Rad, Hercules, CA) run under OpenWindows 3.6, protein spots (features) common to the compared gels were assigned as "landmarks." The gel images were automatically aligned and the remaining features matched between gels. In this way, features that were new or absent from a set of gels could be identified. On the basis of this gel pattern matching and subsequent quantification, proteins were tentatively assigned as constitutive or altered in expression. Quantification of the optical density (OD) of each feature over its area (vol) as a percentage of the total OD over the area of whole gel image (\%vol) was used as a measure of changes in protein expression. When a difference of at least 2.5 times between features from the compared gels was found, this feature was marked as being differentially displayed in the figures. MELANIE 2.3 was also used to determine the relative molecular masses of the proteins by co-electrophoresis with the following standard proteins (Amersham Pharmacia Biotech): phosphorylase b (94 kDa), albumin (67 $\mathrm{kDa})$, ovalbumin (43 kDa), carbonic anhydrase (30 kDa), trypsin inhibitor $(20.1 \mathrm{kDa})$, and lactalbumin $(14.4 \mathrm{kDa})$.

\section{Electroblotting, N-terminal sequencing, and MALDI-TOF MS analysis.}

Electroblotting onto polyvinylidene difluoride membranes (PVDF) (Bio-Rad) was done (Guerreiro et al. 1997) with the exception of electrotransfer being performed at $0.9 \mathrm{~mA} / \mathrm{cm}^{2}$ for $90 \mathrm{~min}$. Selected Coomassie (R-250)-stained spots were excised from dried membranes with scalpel blades and sent for either N-terminal sequencing or MALDI-TOF MS analysis. Spots for MALDI-TOF MS analysis were also taken from preparative gels stained for $24 \mathrm{~h}$ with a colloidal Coomassie stain modified from Neuhoff (Neuhoff et al. 1988). The composition of the colloidal Coomassie stain was obtained from the Australian Proteome Analysis Facility (Macquarie University, Sydney, Australia) 2-DE Manual and was as follows: $0.1 \%$ (wt/vol) Coomassie G-250 (Bio-Rad), 17\% (wt/vol) $\left(\mathrm{NH}_{4}\right)_{2} \mathrm{SO}_{4}, 3 \%$ (wt/vol) $\mathrm{H}_{3} \mathrm{PO}_{4}, 34 \%$ (vol/vol) methanol. The gel was destained in $1 \%$ (vol/vol) acetic acid.

$\mathrm{N}$-terminal amino acid sequencing of PVDF protein spots was done on a PROCISE 494-01 sequencer system (PerkinElmer Applied Biosystems, Foster City, CA). The N-terminal sequences were used to interrogate data bases with Webaccessible search programs such as fastA and TfastA, available online from ANGIS, and fasta3, available online from the EMBL Outstation of the European Bioinformatics Institute (to identify homology to proteins already in protein and nucleic acid data bases. Data bases searched included SWISS-PROT, non-redundant (NR) protein and non-redundant (NR) nucleic acid data bases and Swall NR protein sequence data base plus SwissProt, TrEMBL and TrEMBLNew, respectively.

MALDI-TOF MS was used to determine the masses of the peptides generated following enzymatic digestion of an individual, isolated protein (Wheeler et al. 1996). These PMFs 
were measured with a Micromass TofSpec 2E Time of Flight Mass Spectrometer (Waters Corporation, Milford, MA) at the Australian Proteome Analysis Facility following tryptic digestion. These PMFs were then used to search protein and nucleic acid data bases with the PeptIdent program available online from ExPASy. This program compares the measured PMFs with computer-generated theoretical digests of the proteins in the data bases to look for possible matches based on PMF homology. Searches of Swiss-Prot and TrEMBL bacterial data bases were done for proteins derived from $S$. meliloti grown in culture whereas all data bases were searched for bacteroid proteins. Isoelectric point and molecular mass windows of \pm 1.0 unit and $\pm 20 \%$, respectively, were used. Initial searches were conducted with a mass accuracy of \pm 0.1 Da but the accuracy was increased to $\pm 0.5 \mathrm{Da}$ if no matches were found. Confidence in the PMF matches was based on multiple criteria including the species of the matching peptide, the difference in the number of matching peptides between the first and second matches, the number of PMF matches, number of missed cleavages, percent sequence coverage, and compatibility of isoelectric and molecular mass of the analyzed and data base protein (Wilkins and Gooley 1997).

\section{S. meliloti chromosome BLAST server interrogation with MALDI-TOF MS-generated PMFs.}

PMFs generated by MALDI-TOF MS analysis of trypsindigested proteins were also used to interrogate an incomplete $S$. meliloti $1 \mathrm{X}$ genome data base generated by Melanie Barnett and S. R. Long at the Department of Biological DNA Sequencing and Technology Center. The DNA sequences in this data base were translated in all six reading frames with software at the Australian Proteome Analysis Facility (Macquarie University, Sydney, Australia). The resulting protein sequences were then theoretically digested with trypsin to give predicted PMFs. PMFs of individual protein spots generated from MALDI-TOF MS analysis were then compared with these "theoretical" PMFs with the MassLynx version 3.4 browser (Micromass, Manchester, UK). The theoretical amino acid sequence from the open reading frames to which they matched was then used to interrogate the $S$. meliloti chromosome BLAST server available over the Web (links to both the BLAST server at NCBI and the $S$. meliloti chromosome BLAST server are available online from INRA). In this way, protein homology from the open reading frames could be linked to the PMF lists. The criteria for confidence in a match were similar to that described for direct PMF searches of nonredundant protein data bases. Although the results of the $S$. meliloti data base searches were viewed with a lower level of confidence than those of Swiss-Prot and TrEMBL bacterial data base searching because of the two-step matching process, in most cases the two searches gave the same match (see Tables 6 to 9). Agreement between the data bases is expected to improve as more $S$. meliloti sequence data become available.

\section{ACKNOWLEDGMENTS}

Special thanks go to Barry Rolfe for his input and enthusiastic discussions and to S. R. Long and colleagues for providing access to $S$. meliloti DNA sequence data. Sequence data for Sinorhizobium meliloti was generated by Melanie Barnett and S. R. Long at the Department of Biological DNA Sequencing and Technology Center (online at the Stanford University Web site). We would also like to thank Jill McGovern from the Biomolecular Resource Facility, Australian National University, for N-terminal sequence analysis and Peter Haines from the Australian Proteome Analysis Facility, for MALDI-TOF MS analysis. This research has been facilitated by access to the Australian Proteome Analysis Facility established under the Australian Government's Major National Research Facilities Program.

\section{LITERATURE CITED}

An, J. H., and Kim, Y. S. 1998. A gene cluster encoding malonyl-CoA decarboxylase (MatA), malonyl-CoA synthetase (MatB) and a putative dicarboxylate carrier protein (MatC) in Rhizobium trifolii: Cloning, sequencing and expression of the enzymes in Escherichia coli. Eur. J. Biochem. 257:395-402.

Arcondéguy, T., Huez, I., Fourment, J., and Kahn, D. 1996. Symbiotic nitrogen fixation does not require adenylylation of glutamine synthetase I in Rhizobium meliloti. FEMS Microbiol. Lett. 145:33-40.

Arcondéguy, T., Huez, I., Tillard, P., Gangneux, C., de Billy, F., Gojon, A., Truchet, G., and Kahn, D. 1997. The Rhizobium meliloti PII protein, which controls bacterial nitrogen metabolism, affects alfalfa nodule development. Genes Dev. 11:1194-1206.

Barloy-Hubler, F., Capela, D., Barnett, M.J., Kalman, S., Federspiel, N. A., Long, S. R., and Galibert, F. 2000. High-resolution physical map of the Sinorhizobium meliloti 1021 pSyma megaplasmid. J. Bacteriol. 182:1185-1189.

Bergensen, F. J. 1961. The growth of Rhizobium in synthetic media. Aust. J. Biol. Sci. 14:349-360.

Bladergroen, M. R., and Spaink, H. P. 1998. Genes and signal molecules involved in the rhizobia-leguminoseae symbiosis. Curr. Opin. Plant Biol. 1:353-359.

Brewin, N. J. 1998. Tissue and cell invasion by Rhizobium: The structure and development of infection threads and symbiosomes. Pages 417-429 in: The Rhizobiaceae. H. P. Spaink, A. Kondorosi, and P. J. J. Hooykaas, eds. Kluwer Academic Publishers, Dordrecht, The Netherlands.

Capela, D., Barloy-Hubler, F., Gatius, M.-T., Gouzy, J., and Galibert, F. 1999. A high-density physical map of Sinorhizobium meliloti 1021 chromosome derived from bacterial artificial chromosome library. Proc. Natl. Acad. Sci. USA 96:9357-9362.

Cook, D. R. 1999. Medicago truncatula - a model in the making! Curr. Opin. Plant Biol. 2:301-304.

Corbin, D., Ditta, G., and Helinski, D. R. 1982. Clustering of nitrogen fixation (nif) genes in Rhizobium meliloti. J. Bacteriol. 149:221-228.

Cordwell, S. J., Wilkins, M. R., Cerpa-Poljak, A., Gooley, A. A., Duncan, M., Williams, K. L., and Humphery-Smith, I. 1995. Cross-species identification of proteins separated by two-dimensional gel electrophoresis using matrix-assisted laser desorption ionisation/time-offlight mass spectrometry and amino acid composition. Electrophoresis 16:438-443.

Coughlan, S. J., Hastings, C., and Winfrey, R., Jr. 1997. Cloning and characterization of the calreticulin gene from Ricinus communis L. Plant Mol. Biol. 34:897-991.

Dai, K., and Lutkenhaus, J. 1992. The proper ration of FtsZ to FtsA is required for cell division to occur in Escherichia coli. J. Bacteriol. 174:6145-6151.

Dainese-Hatt, P., Fischer, H.-M., Hennecke, H., and James, P. 1999. Classifying symbiotic proteins from Bradyrhizobium japonicum into functional groups by proteome analysis of altered gene expression levels. Electrophoresis 20:3514-3520.

Day, D. A., and Copeland, L. 1991. Carbon metabolism and compartmentation in nitrogen-fixing legume nodules. Plant Physiol. Biochem. 29:185-201.

Day, D. A., Price, G. D., and Udvardi, M. K. 1989. Membrane interface of the Bradyrhizobium japonicum-Glycine max symbiosis: peribacteroid units from soybean nodules. Aust. J. Plant Physiol. 16:69-84.

Dazzo, F. B. 1982. Leguminous root nodules. Pages 431-446 in: Experimental Microbial Ecology. R. G. Burns and J. L. Slater, eds. Blackwell Scientific, Oxford.

de Bruijn, F. J., Rossbach, S., Schneider, M., Ratet, P., Messmer, S., Szeto, W. W., Ausubel, F. M., and Schell, J. 1989. Rhizobium meliloti 1021 has three differentially regulated loci involved in glutamine biosynthesis, none of which is essential for symbiotic nitrogen fixation. J. Bacteriol. 171:1673-1682. 
Driscoll, B. T., and Finan, T. M. 1996. NADP ${ }^{+}$-dependent malic enzyme of Rhizobium meliloti. J. Bacteriol. 178:2224-2231.

Fåhraeus, G. 1957. The infection of clover root hairs by nodule bacteria studied by a simple glass slide technique. J. Gen. Microbiol. 16:374-381.

Finan, T. M., Oresnik, I., and Bottacin, A. 1988. Mutants of Rhizobium meliloti defective in succinate metabolism. J. Bacteriol. 170:3396-3403.

Fischer, H. M. 1994. Genetic regulation of nitrogen fixation in rhizobia. Microbiol. Rev. 58:352-386.

Gage, D. J., and Long, S. R. 1998. Alpha-galactoside uptake in Rhizobium meliloti: Isolation and characterization of agpA, a gene encoding a periplasmic binding protein required for melibiose and raffinose utilization. J. Bacteriol. 180:5739-5748.

Gendron, N., Breton, R., Champagne, N., and Lapointe, J. 1992. Adenylosuccinate lyase of Bacillus subtilis regulates the activity of the glutamyltRNA synthetase. Proc. Natl. Acad. Sci. USA 89:5389-5392.

Girard, L., Valderrama, B., Palacios, R., Romero, D., and Dávila, G. 1996. Transcriptional activity of the symbiotic plasmid of Rhizobium etli is affected by different environmental conditions. Microbiology 142:2847-2856.

Görg, A., Boguth, G., Obermaier, C., Posch, A., and Weiss, W. 1995. Two-dimensional polyacrylamide gel electrophoresis with immobilized $\mathrm{pH}$ gradients in the first dimension (IPG-DALT): The state of the art and the controversy of vertical versus horizontal systems. Electrophoresis 16:1079-1086.

Görg, A., Obermaier, C., Boguth, G., and Weiss, W. 1999. Recent developments in two-dimensional gel electrophoresis with immobilized $\mathrm{pH}$ gradients: Wide $\mathrm{pH}$ gradients up to $\mathrm{pH} 12$, longer separation distances and simplified procedures. Electrophoresis 20:712-717.

Guerreiro, N., Djordjevic, M. A., and Rolfe, B. G. 1999. Proteome analysis of the model microsymbiont Sinorhizobium meliloti: Isolation and characterisation of novel proteins. Electrophoresis 20:818-825.

Guerreiro, N., Redmond, J. W., Rolfe, B. G., and Djordjevic, M. A. 1997. New Rhizobium leguminosarum flavonoid-induced proteins revealed by proteome analysis of differentially displayed proteins. Mol. Plant-Microbe Interact. 10:506-516.

Humphery-Smith, I., Cordwell, S. J., and Blackstock, W. P. 1997. Proteome research: complementarity and limitations with respect to the RNA and DNA worlds. Electrophoresis 18:1217-1242.

Kahn, M. L., McDermott, T. R., and Udvardi, M. K. 1998. Carbon and nitrogen metabolism in rhizobia. Pages 461-483 in: The Rhizobiaceae. H. P. Spaink, A. Kondorosi, and P. J. J. Hooykaas, eds. Kluwer Academic Publishers, Dordrecht, The Netherlands.

Kamo, M., Kawakami, T., Miyatake, N., and Tsugita, A. 1995. Separation and characterization of Arabidopsis thaliana proteins by twodimensional gel electrophoresis. Electrophoresis 16:423-430.

Kneen, B. E., and LaRue, T. A. 1988. Induced symbiosis mutants of pea (Pisum sativum) and sweetclover (Melilotus alba annua). Plant Sci. 58:177-182.

Kurz, W. G., and LaRue, T. A. 1977. Citric acid cycle enzymes and nitrogenase in nodules of Pisum sativum. Can. J. Microbiol. 23:11971200.

Latch, J. N., and Margolin, W. 1997. Generation of buds, swellings, and branches instead of filaments after blocking the cell cycle of Rhizobium meliloti. J. Bacteriol. 179:2373-2381.

Link, A. J., Robison, K., and Church, G. M. 1997. Comparing the predicted and observed properties of proteins encoded in the genome of Escherichia coli K-12. Electrophoresis 18:1259-1313.

Margolin, W., Corbo, J. C., and Long, S. R. 1991. Cloning and characterization of a Rhizobium meliloti homolog of the Escherichia coli cell division gene ftsZ. J. Bacteriol. 173:5822-5830.

Margolin, W., and Long, S. R. 1994. Rhizobium meliloti contains a novel second homolog to the cell division gene ftsZ. J. Bacteriol. 176: 2033-2043.

McDermott, T. R., and Kahn, M. L. 1992. Cloning and mutagenesis of the Rhizobium meliloti isocitrate dehydrogenase gene. J. Bacteriol. 174: 4790-4797.

Molloy, M. P. 2000. Two-dimensional electrophoresis of membrane proteins using immobilized pH gradients. Analytical Biochem. 280:1-10.

Molloy, M. P., Herbert, B. R., Walsh, B. J., Tyler, M. I., Traini, M., Sanchez, J.-C., Hochstrasser, D. F., Williams, K. L., and Gooley, A. A. 1998. Extraction of membrane proteins by differential solubilization for separation using two-dimensional gel electrophoresis. Electrophoresis 19:837-844.

Münchbach, M., Dainese, P., Staudenmann, W., Narberhaus, F., and
James, P. 1999. Proteome analysis of heat shock protein expression in Bradyrhizobium japonicum. Eur. J. Biochem. 264:39-48.

Neuhoff, V., Arold, N., Taube, D., and Ehrhardt, W. 1988. Improved staining of proteins in polyacrylamide gels including isoelectric focusing gels with clear background at nanogram sensitivity using Coomassie brilliant blue G-250 and R-250. Electrophoresis 9:255-262.

Ogawa, J., and Long, S. R. 1995. The Rhizobium meliloti groELc locus is required for regulation of early nod genes by the transcription activator NodD. Genes Dev. 9:714-729.

Oke, V., and Long, S. R. 1999. Bacterial genes induced within the nodule during the Rhizobium-legume symbiosis. Mol. Microbiol. 32:837849.

Perret, X., Freiberg, C., Rosenthal, A., Broughton, W. J., and Fellay, R. 1999. High resolution transcriptional analysis of the symbiotic plasmid of Rhizobium sp. NGR234. Mol. Microbiol. 32:415-425.

Pocard, J. A., Vincent, N., Boncompagni, E., Smith, L. T., Poggi, M. C., and Le Rudulier, D. 1997. Molecular characterization of the bet genes encoding glycine betaine synthesis in Sinorhizobium meliloti 102F34. Microbiology 143:1369-1379.

Rabilloud, T. 1992. A comparison between low background silver diammine and silver nitrate protein stains. Electrophoresis 13:429-439.

Rabilloud, T., Vuillard, L., Gilly, C., and Lawrence, J. J. 1994. Silverstaining of proteins in polyacrylamide gels: a general overview. Cell. Mol. Biol. 40:57-75.

Ronson, C. W., Nixon, B. T., Albright, L. M., and Ausubel, F. M. 1987. Rhizobium meliloti ntrA (rpoN) gene is required for diverse metabolic functions. J. Bacteriol. 169:2424-2431.

Ross, E. J., Kramer, S. B., and Dalton, D. A. 1999. Effectiveness of ascorbate and ascorbate peroxidase in promoting nitrogen fixation in model systems. Phytochemistry 52:1203-1210.

Schultze, M., and Kondorosi, A. 1998. Regulation of symbiotic root nodule development. Annu. Rev. Genet. 32:33-57.

Shatters, R. G., Liu, Y., and Kahn, M. L. 1993. Isolation and characterization of a novel glutamine synthetase from Rhizobium meliloti. J. Biol. Chem. 268:469-475.

Shevchenko, A., Jensen, O. N., Podtelejnikov, A.V., Sagliocco, F., Wilm, M., Vorm, O., Mortensen, P., Shevchenko, A., Boucherie, H., and Mann, M. 1996. Linking genome and proteome by mass spectrometry: large-scale identification of yeast proteins from two dimensional gels. Proc. Natl. Acad. Sci. USA 93:14440-14445.

Udvardi, M. K., and Day, D. A. 1997. Metabolite transport across symbiotic membranes of legume nodules. Annu. Rev. Plant Physiol. Plant Mol. Biol. 48:493-523.

Utrup, L. J., Cary, A. J., and Norris, J. H. 1993. Five nodulation mutants of white sweetclover (Melilotus alba Desr.) exhibit distinct phenotypes blocked at root hair curling, infection thread development, and nodule organogenesis. Plant Physiol. 103:925-932.

Utrup, L. J., and Norris, J. H. 1996. Nodulin gene expression in effective root nodules of white sweetclover (Melilotus alba Desr.) and in ineffective nodules elicited by mutant strains of Rhizobium meliloti. J. Exp. Bot. 47:195-202.

Walshaw, D. L., Wilkinson, A., Mundy, M., Smith, M., and Poole, P. S. 1997. Regulation of the TCA cycle and the general amino acid permease by overflow metabolism in Rhizobium leguminosarum. Microbiology 143:2209-2221.

Wheeler, C. H., Berry, S. L., Wilkins, M. R., Corbett, J. M., Ou, K., Gooley, A. A., Humphery-Smith, I., Williams, K.L., and Dunn, M.J. 1996. Characterisation of proteins from two-dimensional electrophoresis gels by matrix-assisted laser desorption mass spectrometry and amino acid compositional analysis. Electrophoresis 17:580-587.

Wilkins, M. R., and Gooley, A. A. 1997. Protein identification in proteome projects. Pages 35-64 in: Proteome Research: New Frontiers in Functional Genomics. M. R. Wilkins, ed. Springer-Verlag, Berlin.

Wilkins, M. R., Sanchez, J.-C., Williams, K. L., and Hochstrasser, D. F. 1996. Current challenges and future applications for protein maps and post-translational vector maps in proteome projects. Electrophoresis 17:830-838.

Willis, L. B., and Walker, G. C. 1998. Identification of the Rhizobium meliloti alcohol dehydrogenase gene $(a d h \mathrm{~A})$ and heterologous expression in Alcaligenes eutrophus. Biochem. Biophys. Acta 1384:197203.

Zhou, P., and Helmstetter, C. E. 1994. Relationship between ftsZ gene expression and chromosome replication in Escherichia coli. J. Bacteriol. 176:6100-6106. 